\title{
Computational Analysis of the Properties of Post-Keynesian Endogenous Money Systems
}

\author{
Stef Kuypers ${ }^{1}$, Thomas Goorden ${ }^{2}$, and Bruno Delepierre ${ }^{3}$ \\ ${ }^{1}$ Happonomy vzw - stef@happonomy.org \\ 2 thomas.goorden@gmail.com \\ ${ }^{3}$ Happonomy vzw - bruno@happonomy.org \\ July 2, 2021
}

Keywords: Economics, SFC, Growth imperative, Steady State Economy, Money Stock, Money Supply, Green Economy, Green Growth

\begin{abstract}
"Money has always been something of an embarrassment to economic theory. Everyone agrees that it is important; indeed, much of macroeconomic policy discussion makes no sense without reference to money. Yet, for the most part theory fails to provide a good account for it." (Banerjee and Maskin, 1996, p. 955)

The debate about whether or not a growth imperative exists in debt based, interest bearing monetary systems has not yet been settled. It is the goal of this paper to introduce a new perspective in this discussion.

For that purpose an SFC computational model is constructed which simulates a post Keynesian Endogenous Money system without including economic parameters such as production, wages, consumption and savings. A case is made that isolating the monetary system allows for better analysis of the inherent properties of such a system.

Loan demands, which are assumed to happen, are the driving force of the model. Simulations can be run in two modes, each based on a different assumption. Either the growth rate of the money stock is assumed to be constant or the loan rate, expressed as a percentage of the money stock, is assumed to be constant.

Simulations with varying parameters are run in order to determine the conditions under which the model converges to stability, which is defined as converging to a bounded debt rate.

The analysis shows that stability of the model is dependent on net bank profit ratios, expressed relative to their debt assets, remaining below the growth rate of the money stock. Based on these findings it is argued that the question about the existence of a growth imperative in debt based, interest bearing monetary systems needs to be reframed. The question becomes whether a steady state economy can realistically support such a system without destabilising it. In order to answer this question real world behavior of economic actors must be included in the model.

It is concluded that there are indications that it might not be feasible for a steady state economy to support a stable debt based, interest bearing monetary system without strong interventions.
\end{abstract}


However, more research is necessary for a definite answer. Real world observable data should be analysed through the lens of the presented model to bring more clarity.

\section{Introduction}

This paper focuses on an analysis of a computational stock and flow consistent (SFC) model (Nikiforos and Zezza, 2017) based on post Keynesian endogenous money supply theory. This theory, which states that money is created by banks when issueing loans, has started to be more widely accepted since the publication by the Central Bank of England (McLeay and Radia, 2014). It has later been backed by the Deutsche Bundesbank (Deutsche Bundesbank, 2017). Empirical evidence has been found by different authors. A. Werner (Werner 2014, 2016) traced a loan through the computers of a real bank and observed the creation of deposits without any transfer of funds. Nayan et al. published a paper (Nayan et al., 2013) where the use of dynamic panel data analysis with data from 177 countries came to the conclusion that money is created endogenously in the economy through loans.

Currently there is disagreement between ecological economists and others about the existence of an inherent growth imperative in debt based, interest bearing monetary systems (Lietaer et al., 2012, Farley et al., 2013, Arnsperger et al., 2021) or the absence of such an inherent growth imperative (Jackson and Victor, 2015, Cahen-Fourot and Lavoie, 2016, Richters and Siemoneit, 2017).

Although SFC models have been extensively used to support macroeconomic theories (Lavoie and Godley, 2002, Godley, 2004, Kinsella and O'Shea, 2011, Caiani et al., 2016), no SFC models have been found which fully separate the monetary system from the rest of the economy.

All reviewed SFC models include economical parameters such as production, wages and consumption, while it can be argued that these are not part of the monetary system itself. Wages and consumption have no effect on the money stock as a whole, as money is neither created nor destroyed in the transactions between the involved actors. Money is merely moved from one actor holding an account in the aggregate money stock to another. When considering production, the production process by itself does not involve money at all when all necessary conditions - the availability of production means - are met. Money only gets involved when resources needed for production are bought, wages are paid and the final products are sold. All these operations only move money around in the aggregate money stock.

According to "post Keynesian money supply theory" money creation - which goes hand in hand with debt creation - is initiated by loan demands. All papers studied analyse the incentives for these loan demands but these incentives are effectively inconsequential in regards to determining the properties of the monetary system itself. The only requirement is that there is a loan demand. The incentive for this loan demand can simply be assumed. In effect, it turns out monetary systems can be studied without economic parametrisation.

The model presented in this paper is reduced to the minimum elements needed for a post Keynesian money supply model to be simulated: loan demand and settlement of debt. For the puropse of determining the inherent properties of the model, demand for money is assumed while the exact incentive for this demand is factored out.

It is assumed that a post Keynesian money supply model does not inherently result in a growing economy. After determination of the properties of the computational model this assumption is 
analysed for feasibility in conjunction with a reflection on real world economic parameters.

\section{Methodology}

A computational model has been designed which includes the minimum of aggregates necessary to simulate a fully functioning debt based money supply model. The aggregates are the bank sector, the aggregate of all commercial banks, and a private sector, which encompasses all households and organisations.

- Bank sector:

- Supply money on demand through private loans, thereby increasing the money stock.

- Demand payback of outstanding private loans on predefined intervals, thereby decreasing the money stock.

- Private sector:

- Initiates the money supply through private loan demands.

- Pays off outstanding private debts on predefined intervals.

Balance sheet analysis is used to clarify actions executed by the simulations.

\subsection{Money creation through loans}

An increase in money stock looks as follows:

- Step 1: a loan demand is initiated by the private sector.

- Step 2: the bank sector issues the loan, resulting in the following changes to the bank's and the private sector's balance sheets:

Bank sector balance sheet

\begin{tabular}{ll}
\hline Assets & Liabilities \\
\hline + Private debt & + Deposits \\
\hline
\end{tabular}

Private sector balance sheet

\begin{tabular}{ll}
\hline Assets & Liabilities \\
\hline + Deposits & + Private debt \\
\hline
\end{tabular}

\subsection{Money destruction through down-payments}

A reverse operation is caused by the bank sector demanding repayment of loans from the private sector. When a loan instalment is paid to the bank sector together with the accompanying interest, the following balance sheet activity is recorded:

Bank sector balance sheet

\begin{tabular}{ll}
\hline Assets & Liabilities \\
\hline - Private debt (Loan instalment) & - Deposits (Loan instalment) \\
& - Deposits (Interest)
\end{tabular}




\begin{tabular}{ll}
\hline Assets & Liabilities \\
\hline & + Equity (Interest) \\
\hline
\end{tabular}

\section{Private sector balance sheet}

\begin{tabular}{ll}
\hline Assets & Liabilities \\
\hline - Deposits (Loan instalment) & - Private debt (Loan instalment) \\
- Deposits (Interest) & - Equity (Interest) \\
\hline
\end{tabular}

Payment of interest on loans also results in a decrease of deposits. However, since no corresponding activity happens on the asset side of the bank sector's balance sheet, received interest shows up as increased equity. An equal decrease in equity occurs on the private sector's balance sheet, balancing a decrease in assets (deposits). Any bank fees the bank sector receives from the private sector results in similar balance sheet operations and will therefore also result in increased bank sector equity and decreased private sector equity.

\subsection{Bank costs}

Not all income received by the bank sector results in profit. Bank costs paid to the private sector from equity recreates deposits as follows:

Bank sector balance sheet

\begin{tabular}{ll}
\hline Assets & Liabilities \\
\hline & + Deposits (Bank costs) \\
- Equity (Bank costs) \\
\hline
\end{tabular}

Private sector balance sheet

\begin{tabular}{ll}
\hline Assets & Liabilities \\
\hline + Deposits (Bank costs) & + Equity (Bank costs) \\
\hline
\end{tabular}

No corresponding activity happens on the assets side of the bank sector's balance sheet, resulting in only a change in equity for the bank sector and a corresponding and opposite change in equity for the private sector.

\subsection{Profit retention}

Bank sector income, interest plus fees, and bank costs partially offset each other. It is assumed that the net profit made by the bank sector is equal to or greater than zero. Only net profit, retained by the bank sector, is considered in the simulation. This profit retention rate is expressed as a percentage of owned private debt. Symmetrically, the payments made by the private sector are limited to the downpayment of the loans plus the net profit retained by the bank sector. 


\section{Model description}

The computational model is designed in such a way that simulations can be run in two different modes. Either the growth rate of the money stock is fixed or the loan demand, expressed as a percentage of the money stock, is fixed.

The choice of using money stock growth as a driver for the first mode of the simulation is based on real world observations. Indeed, looking at the data supplied by the statistical warehouse of the $\mathrm{ECB}^{1}$, the money stock $\left(\mathrm{M} 2^{2}\right)$ in Europe has, although not smoothly, been on the rise over the last 4 decades. Although the growth rate of the money stock has not been constant it has been bounded. An average growth rate is used in the simulations.

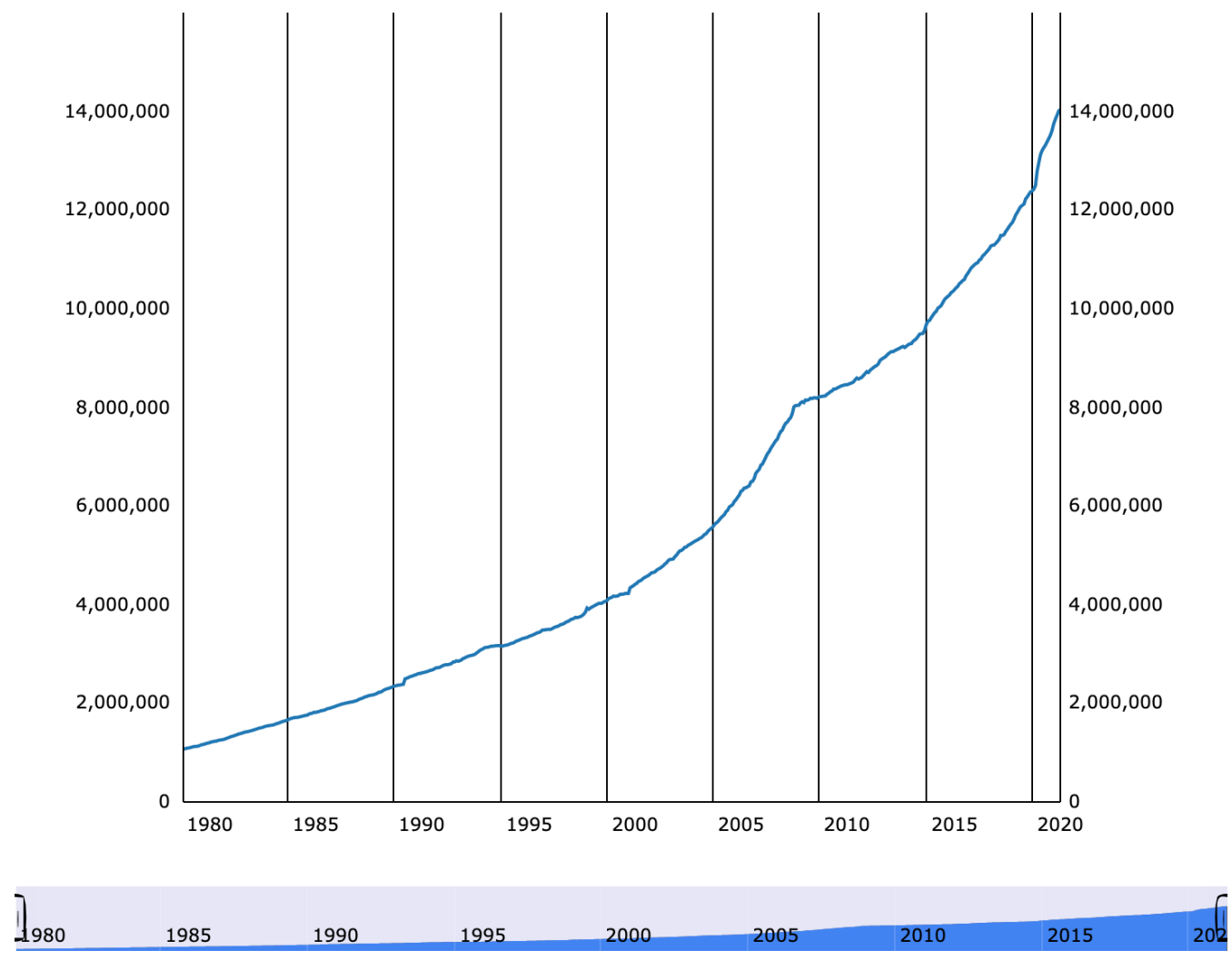

Fig. 1 - M2 Europe 


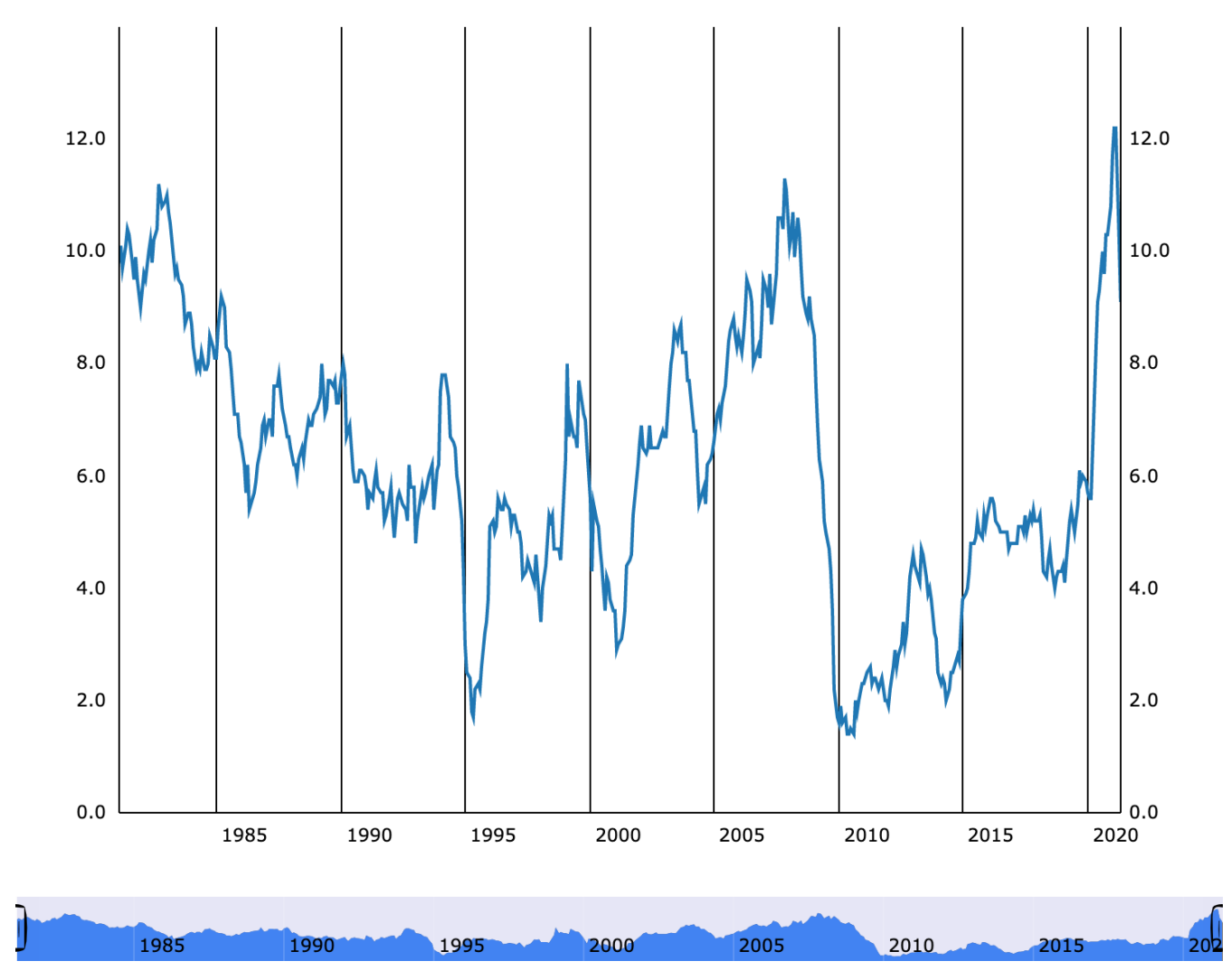

Fig. 2 - M2 growth Europe

The second mode of the simulation is based on the assumption that an unbounded loan demand is unrealistic. A fixed loan rate, a percentage relative to the money stock, is set to initialise this mode.

The computational model is initialised with the following parameters:

- Growth mode

- g: growth rate of the money stock.

- Loan demand mode

- LR: loan rate expressed as a percentage of the current money stock.

- Both modes:

- $C$ : number of cycles. Each cycle is interpreted as one year.

- The initial state of all balance sheets.

- Parameters for the bank sector:

- m: loan maturity.

- $p$ : profit retention rate on debt.

Variables tracked during the simulation:

- $t$ : cycle number.

- $M_{t}$ : money stock.

- $D_{t}$ : private debt held by the bank.

- $D R_{t}=\frac{D_{t}}{M_{t}}$ : debt ratio. 
- $L_{t}$ : size of the loan demand.

- $I_{t}$ : instalment due.

\section{Simulations}

The goal of the following simulations is to determine the conditions under which the model remains stable. Assuming that an ever rising $D R$ is not feasible in a real world economy, stability of the model is defined as $D R$ converging to a bounded value.

Initial $M_{0}$ is created with a loan $L_{0}$. Every subsequent cycle a new loan $L_{t}$ is created according to the parameters of the simulation mode. Loans are paid off over a period equal to their maturity $m$, resulting in $m$ instalments $i$ which are all equal to $\frac{L_{t}}{m}$. In the text below $I_{t}$ is used, being the sum of all $i$ being due at cycle $t$. Loans which have reached their maturity are retired.

$p$ does not necessarily correspond with real world values. This is inconsequential for determining the properties of the model.

$D R_{t}$ is calculated.

\subsection{Fixed growth rate}

The following simulations assume a fixed growth rate $g$ :

- $\forall t, \frac{M_{t}-M_{t-1}}{M_{t-1}}=g$

Each cycle the following equations are processed:

- $M_{\text {target }}=(1+g) M_{t-1}$

- $D_{t}=D_{t-1}-I_{t}$

- $M_{t}=M_{t-1}-I_{t}-p D_{t-1}$

- $L_{t}=M_{\text {target }}-M_{t}$

- $M_{t} \rightarrow M_{t}+L_{t}$

- $D_{t} \rightarrow D_{t}+L_{t}$

The following output is analysed:

- $D R_{t}=\frac{D_{t}}{M_{t}}$

\subsubsection{Mathematical analysis}

For a fixed growth rate scenario, it is possible to derive an analytical solution for $D R$ with a fixed growth rate $g$ for $M$. This solution eliminates $L$ from the equations.

From the balance sheet analysis it can be concluded that $M$ plus bank sector equity $(E)$ equals $D$. Expressed as continuous functions:

(1) $M(t)+E(t)=D(t)$

A fraction of $M$ equal to $p D$ is converted into $E$ each cycle:

(2) $E(t)=E(t-1)+D(t-1) p$

$M$ grows by percentage $g$ each cycle: 
(3) $M(t)=M_{0}(1+g)^{t}$

We can define:

(4) $D R(t)=\frac{D(t)}{M(t)}$

(5) $\Rightarrow D(t)=D R(t) M(t)$

(6) $\Rightarrow E(t)=(D R(t)-1) M(t)$

substituting (5) and (6) in (2) gives us the recurrence relation for $s(t)$ :

(7) $\Rightarrow D R(t)=\frac{D R(t-1)(1+p)-p}{1+g}+1$

the solution to which is:

(8) $\Rightarrow D R(t)=\frac{p\left(\frac{1+p}{1+g}\right)^{t}-g}{p-g}$

$\mathbf{g}=\mathbf{0}$ (no-growth scenario for $\mathbf{M}$ ) If $g=0, D R(t)$ reduces to $(p+1)^{t}$

$\mathbf{p}=\mathbf{g} \quad \lim _{p \rightarrow g} D R(t)=\frac{g t}{1+g}+1$

$\mathbf{p}=\mathbf{0}$ (no profit) $D R(t)=1$

$\mathbf{p}<\mathbf{g} \quad \lim _{t \rightarrow \inf } D R(t)=\frac{g}{g-p}$

\subsubsection{Plots}

With each plot the output from the mathematical functions is plotted as fDR alongside the output of the simulation for comparison.

using EconoSim

using MoneySim

$\mathrm{g}=0 \%, \mathrm{p}=0 \%$

data $=$ simulate_fixed_g $(\mathrm{g}=0, \mathrm{p}=0, \mathrm{~m}=20$, cycles $=100)$

plot_debt_ratio(data, func_plot $=$ true) 


\section{Debt ratio (100 years)}

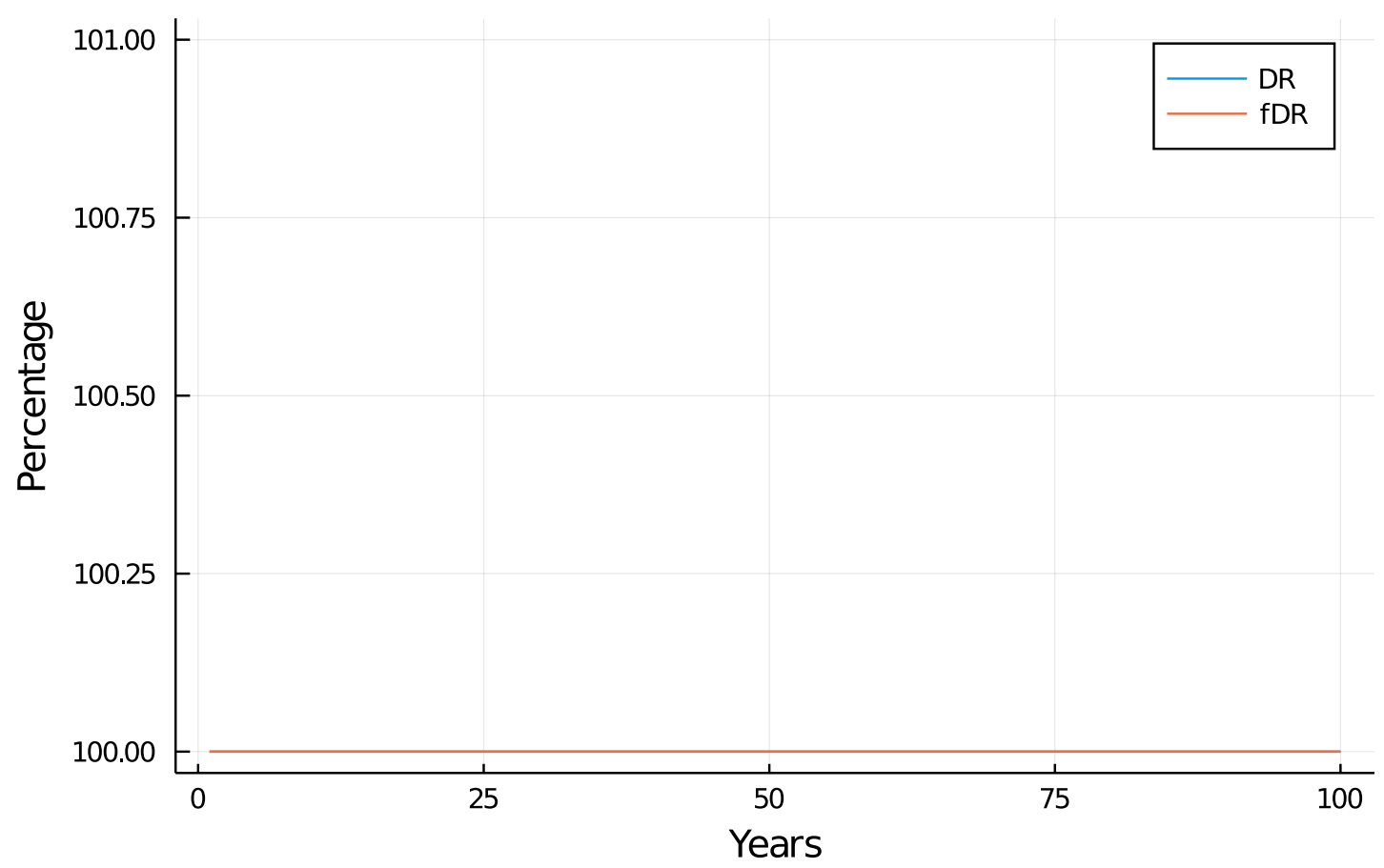

$$
\begin{aligned}
& \text { print_last_ratio(debt_ratio(data), "DR") } \\
& \mathrm{DR}(100)=100.0 \% \\
& \mathbf{g}=\mathbf{5} \%, \mathbf{p}=\mathbf{0} \% \\
& \begin{array}{l}
\text { data }=\text { simulate_fixed_g }(\mathrm{g}=0.05, \mathrm{p}=0, \mathrm{~m}=20, \text { cycles }=100) \\
\text { plot_debt_ratio(data, func_plot }=\text { true })
\end{array}
\end{aligned}
$$




\section{Debt ratio (100 years)}

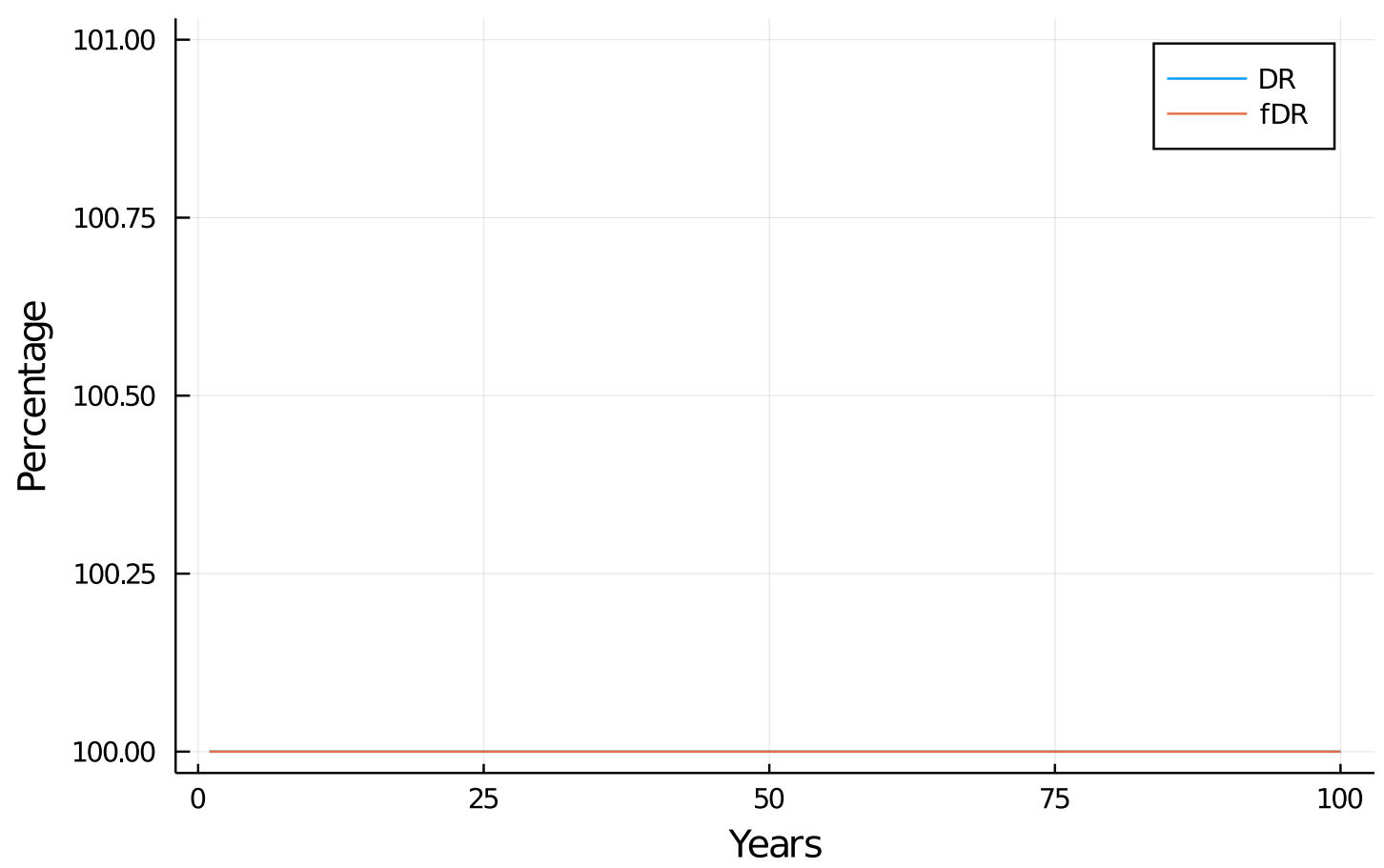

$$
\begin{aligned}
& \text { print_last_ratio(debt_ratio(data), "DR") } \\
& \mathrm{DR}(100)=100.0 \% \\
& \mathbf{g}=\mathbf{5} \%, \mathbf{p}=\mathbf{1} \% \\
& \begin{array}{l}
\text { data }=\text { data }=\text { simulate_fixed_g }(\mathrm{g}=0.05, \mathrm{p}=0.01, \mathrm{~m}=20, \text { cycles }=100) \\
\text { plot_debt_ratio (data, func_plot }=\text { true })
\end{array}
\end{aligned}
$$




\section{Debt ratio (100 years)}
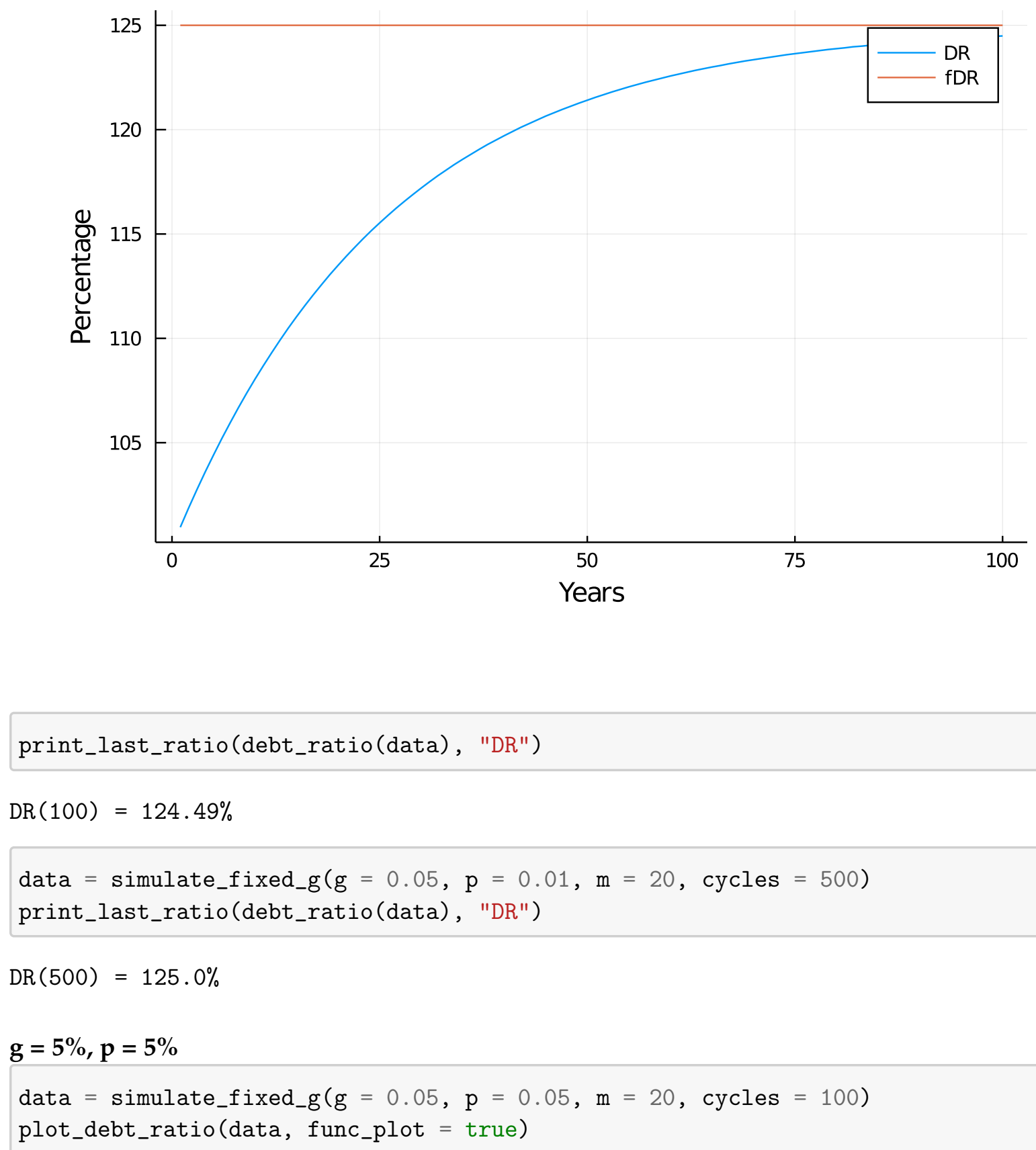


\section{Debt ratio (100 years)}

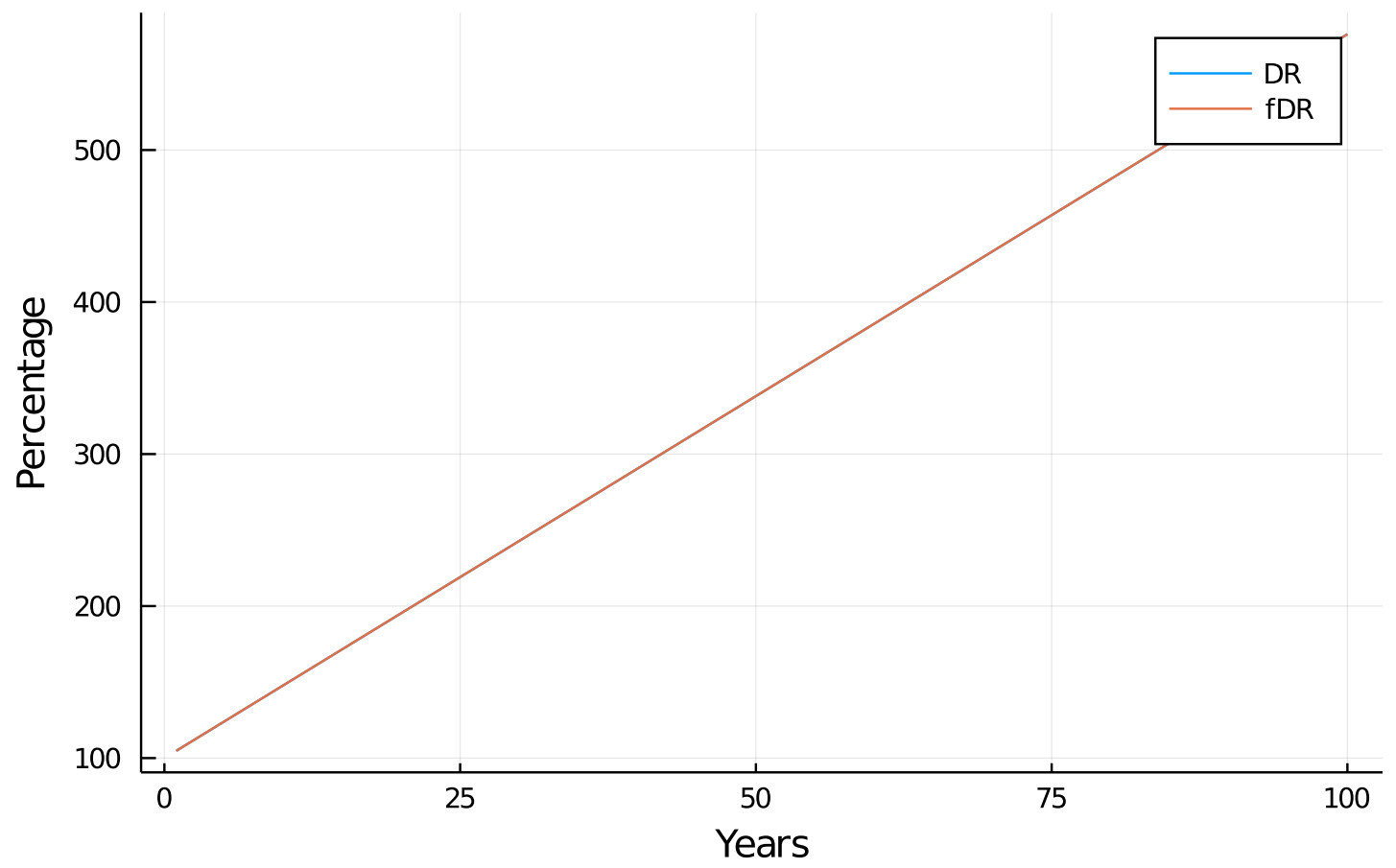

$$
\begin{aligned}
& \text { print_last_ratio(debt_ratio(data), "DR") } \\
& \mathrm{DR}(100)=576.19 \% \\
& \mathbf{g}=\mathbf{5} \%, \mathbf{p}=\mathbf{1 0} \% \\
& \begin{array}{l}
\text { data }=\text { simulate_fixed_g }(\mathrm{g}=0.05, \mathrm{p}=0.1, \mathrm{~m}=20, \text { cycles }=100) \\
\text { plot_debt_ratio(data, func_plot }=\text { true })
\end{array}
\end{aligned}
$$




\section{Debt ratio (100 years)}

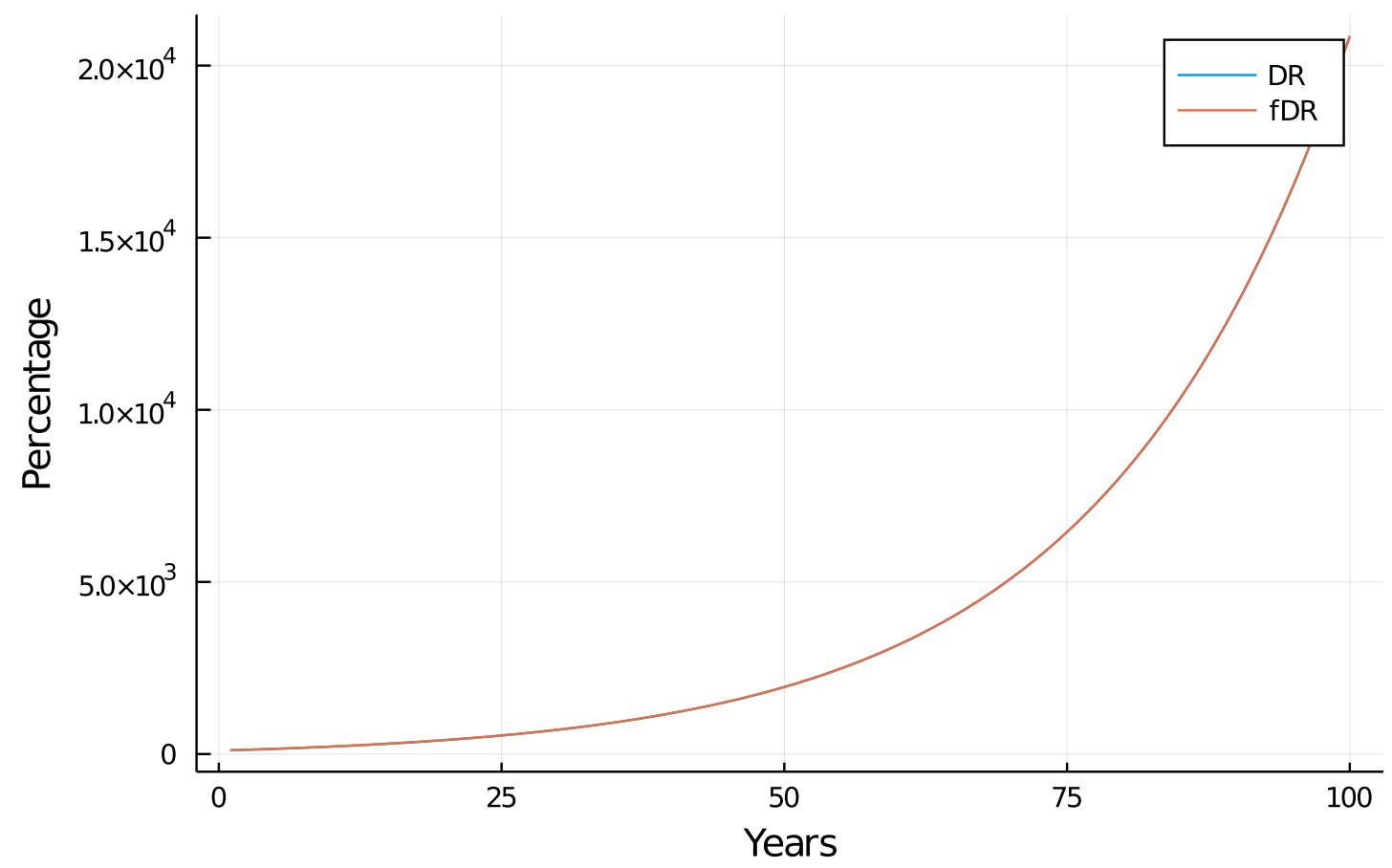

print_last_ratio(debt_ratio(data), "DR")

$\mathrm{DR}(100)=20858.91 \%$

\subsection{Fixed Loan Rate}

Although $L$ can be mathematically factored out, $g$, which can be observed from real world data, is the result of the balance between $L, I$ and $p D$ :

- $g_{t}=\frac{M_{t-1}+L_{t}-I_{t}-p D_{t}}{M_{t-1}}$

The following simulations assume a fixed $L R$ :

- $\forall t, \frac{L_{t}}{M_{t}}=L R$

- $M_{t}=M_{t-1}-I_{t}-p D_{t}+L_{t}$

- $\Rightarrow \frac{L_{t}}{M_{t-1}-I_{t}-p D_{t-1}+L_{t}}=L R$

- $\Rightarrow L_{t}=L R\left(M_{t-1}-I_{t}-p D_{t-1}+L_{t}\right)$

- $\Rightarrow L_{t}=\frac{M_{t-1}-\left(I_{t}+p D_{t-1}\right)}{1-L R} L R$

Each cycle, the following equations are processed:

- $L_{t}=\frac{M_{t-1}-\left(I_{t}+p D_{t-1}\right)}{1-L R} L R$

- $M_{t}=M_{t-1}-\left(I_{t}+p D_{t-1}\right)+L_{t}$

- $D_{t}=D_{t-1}-I_{t}+L_{t}$

The following output is analysed: 
- $M_{t}$

- $g_{t}=\frac{M_{t}-M_{t}-1}{M_{t-1}}$

- $D R_{t}=\frac{D_{t}}{M_{t}}$

$I_{t}$ is dependant on $m$ and therefore $L_{t}$ will vary for different values of $m$. The effects are examined in the simulations.

Simulations stop automatically when $M_{t} \leq 0$. The effective runtime displayed equals the number of years where $M_{t}>0$.

\subsubsection{Plots}

$$
\mathrm{LR}=15 \%, \mathrm{p}=\mathbf{0 . 8 \%} \mathrm{m}=20 \text { years }
$$

data $=$ simulate_fixed_LR $(L R=0.15, p=0.008, m=20$, cycles $=500)$

plot_money_stock(data)

\section{Money stock (500 years)}

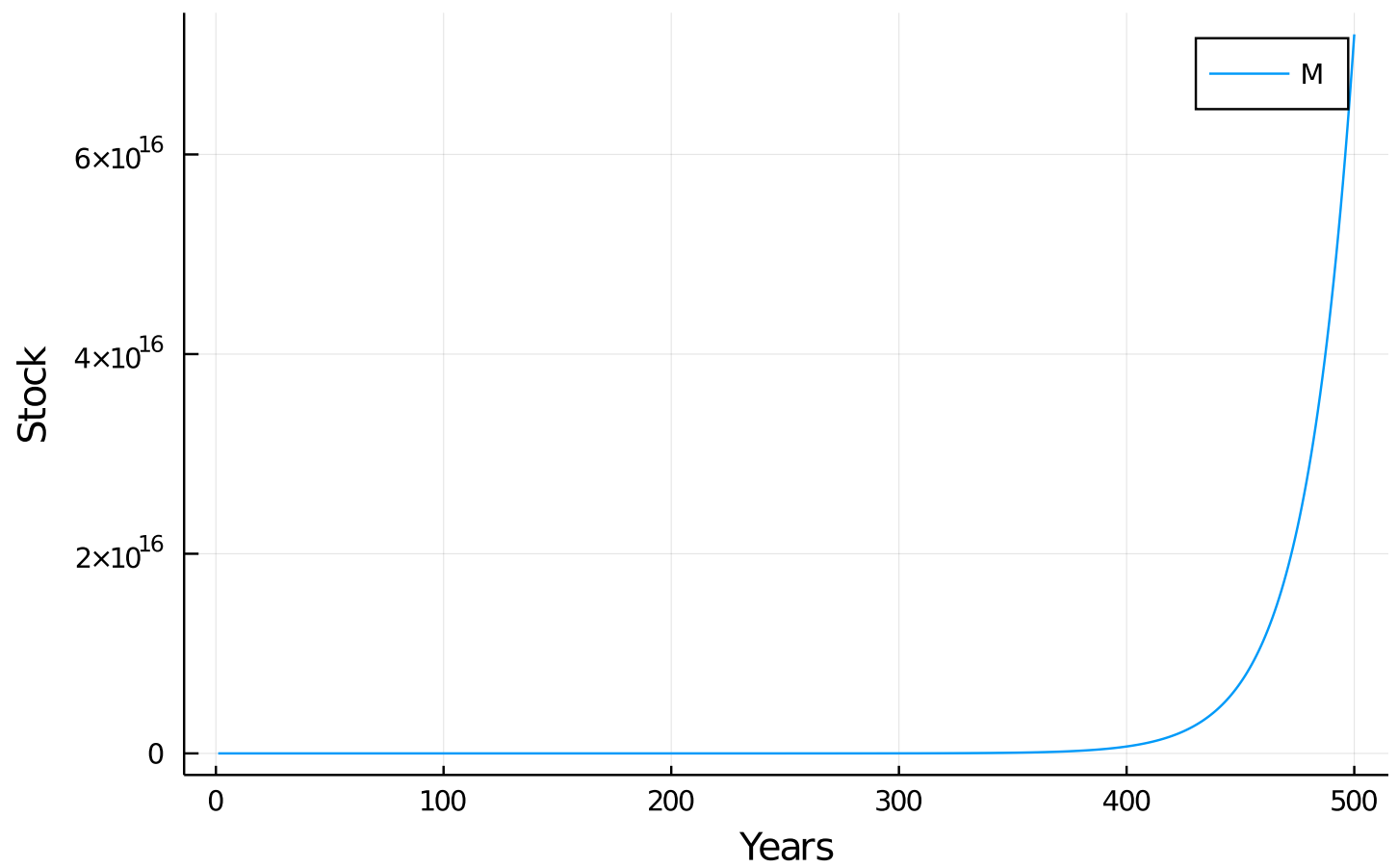

plot_growth_ratio(data) 


\section{Growth ratio (500 years)}

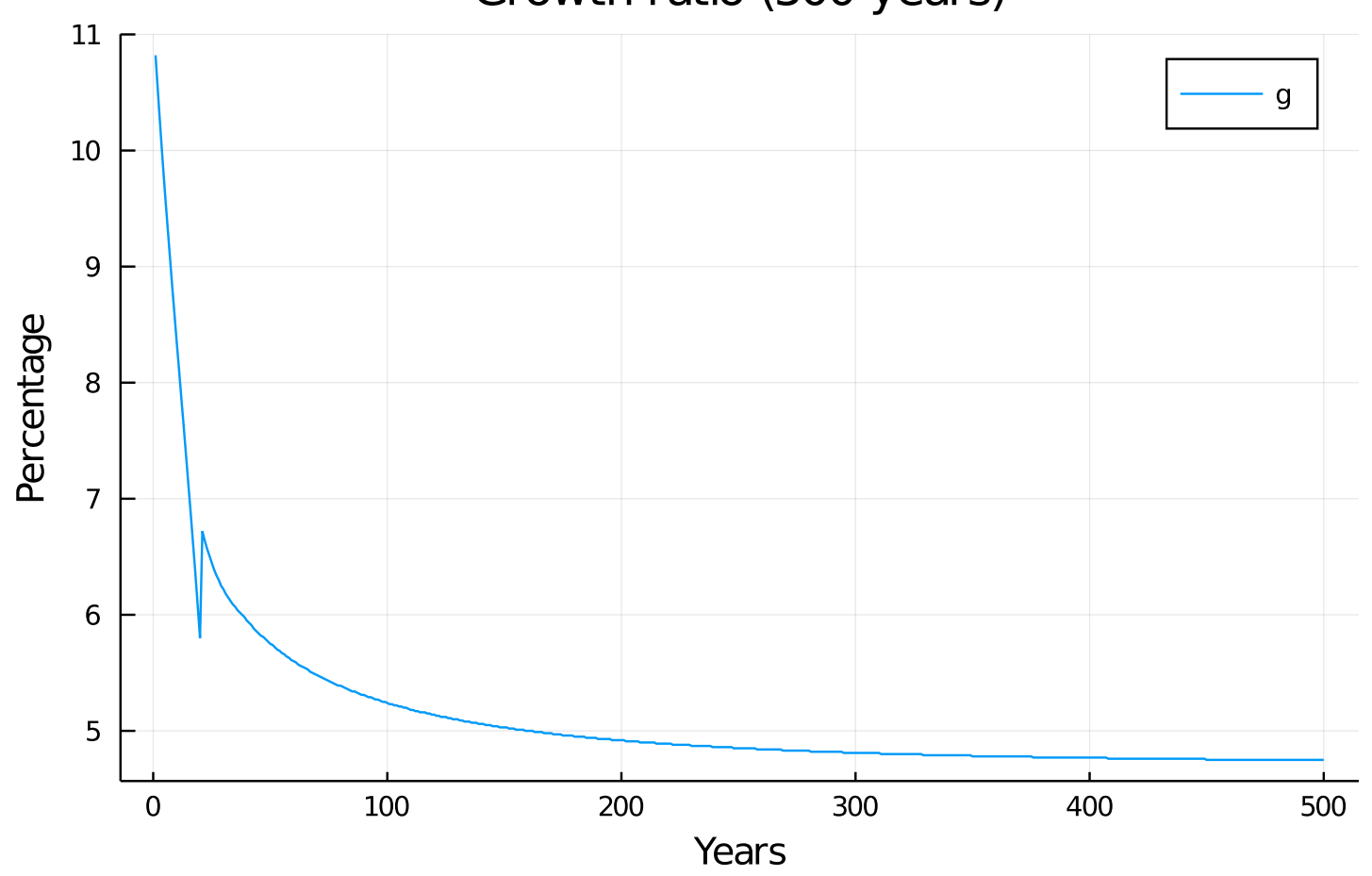

plot_debt_ratio(data)

Debt ratio (500 years)

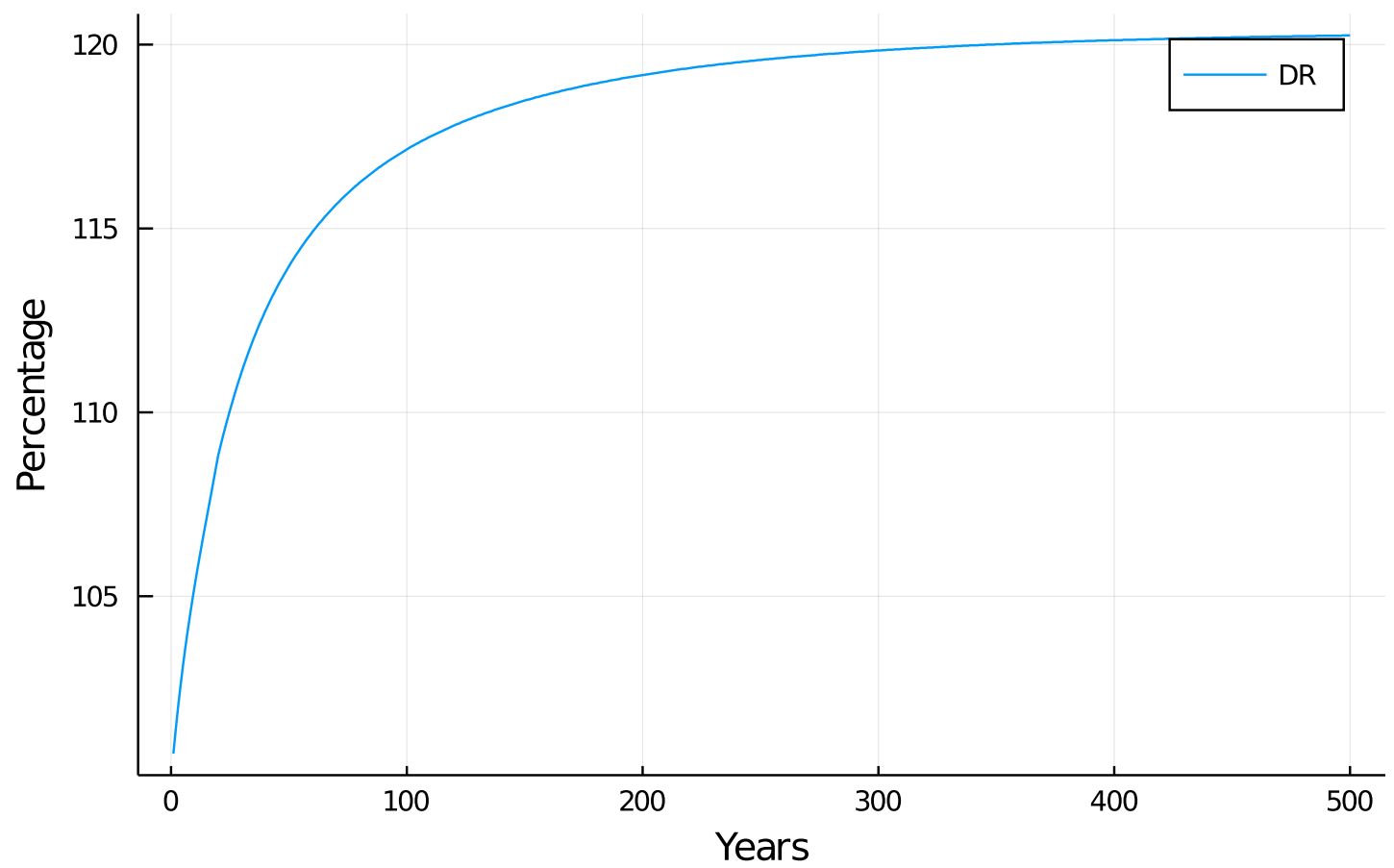




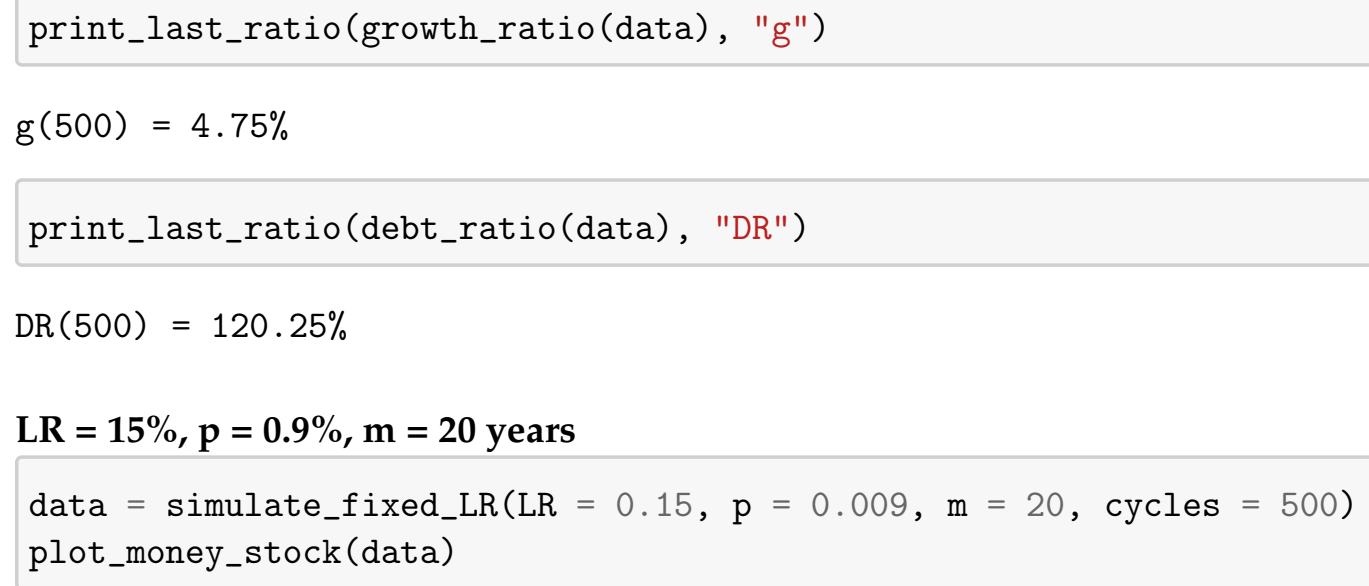

\section{Money stock (193 years)}

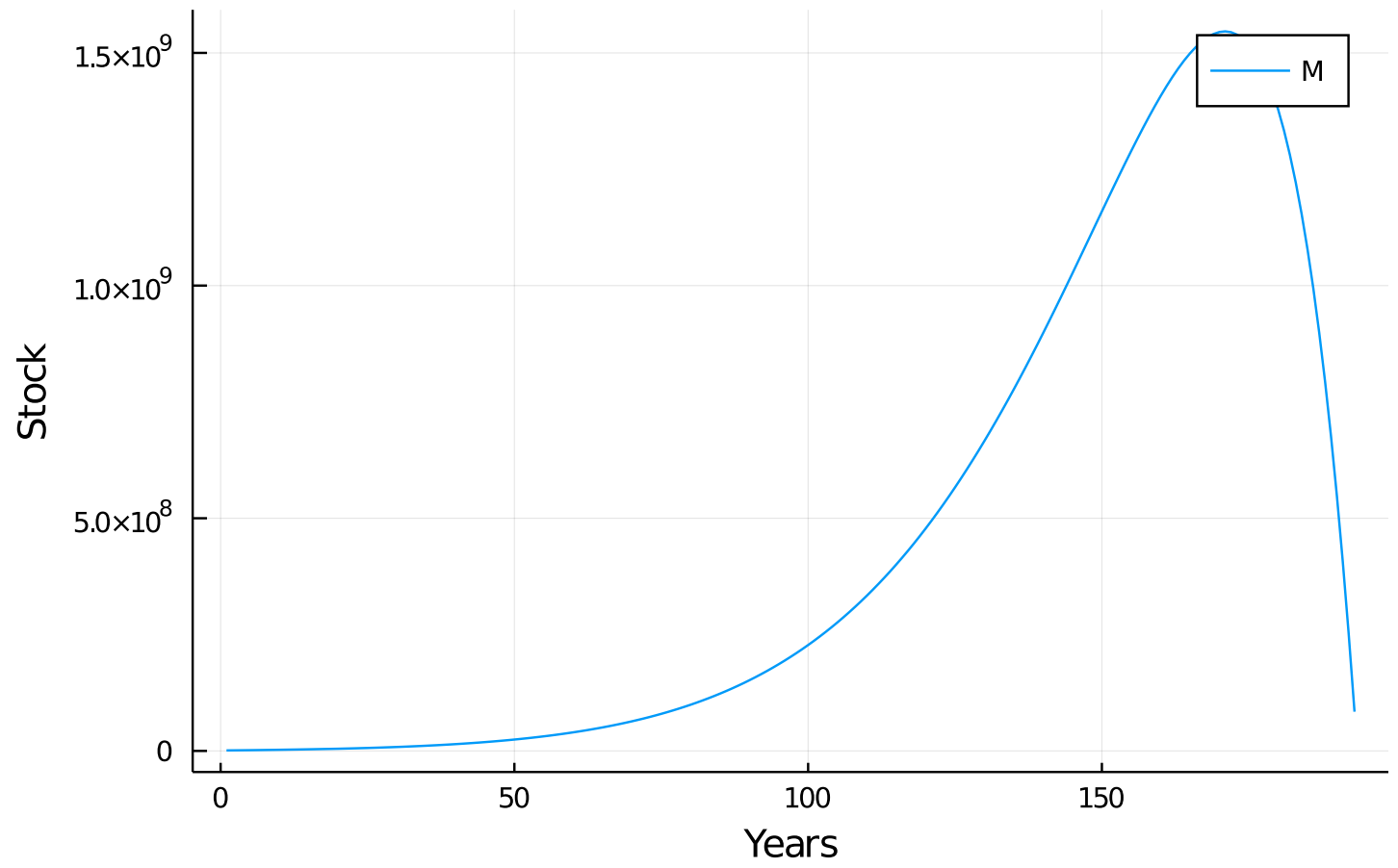

plot_growth_ratio(data) 


\section{Growth ratio (193 years)}

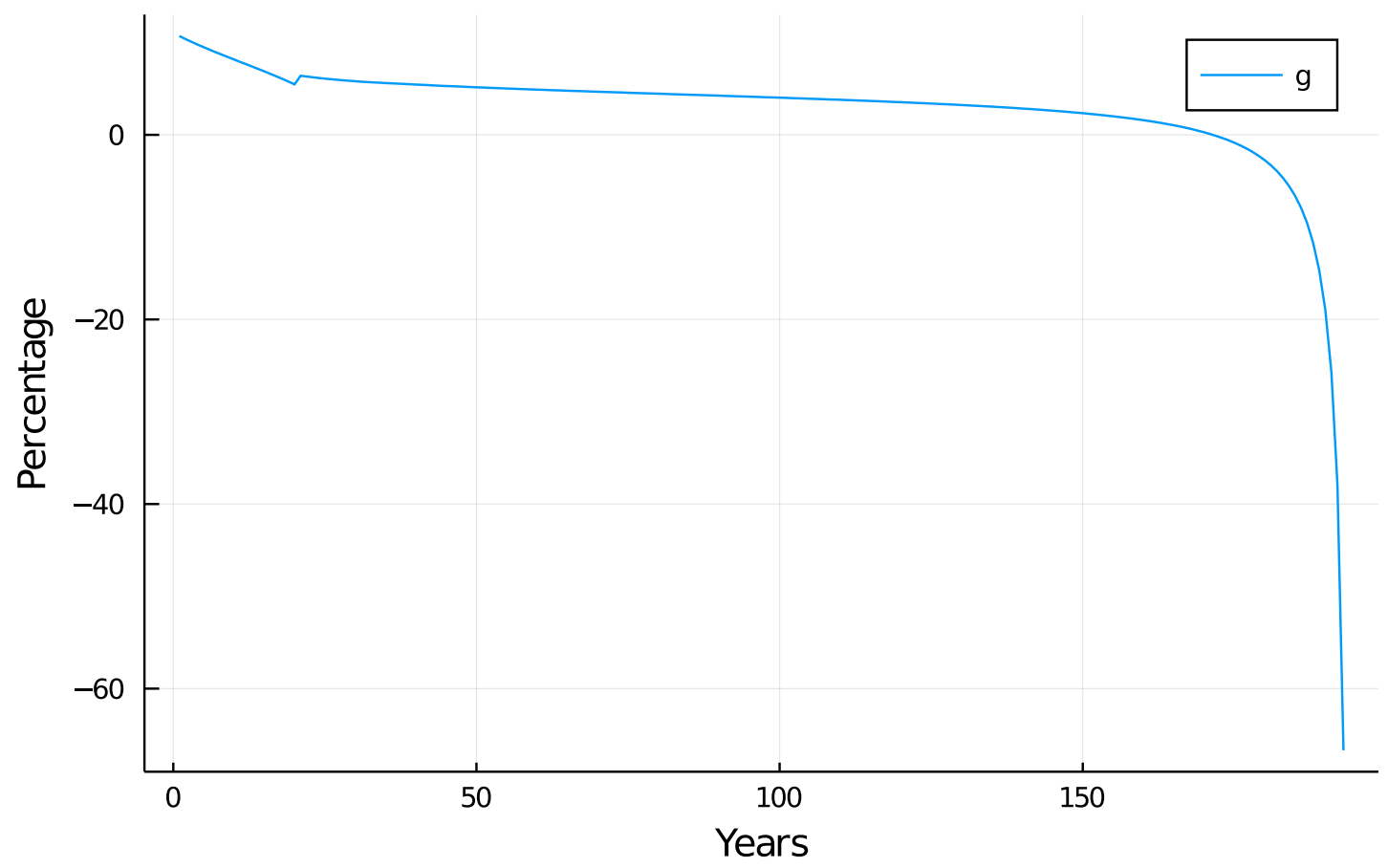

plot_debt_ratio(data)

Debt ratio (193 years)

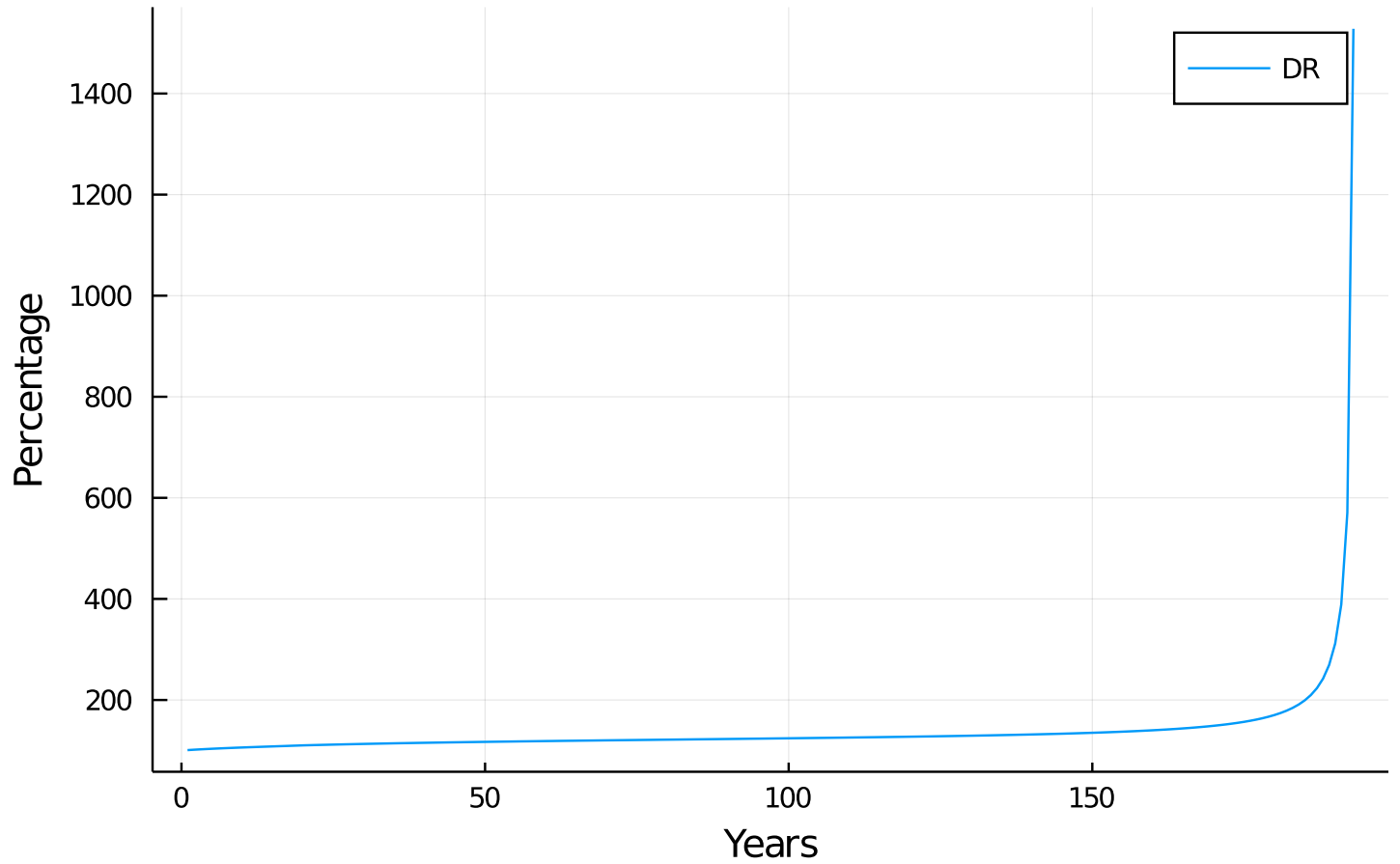




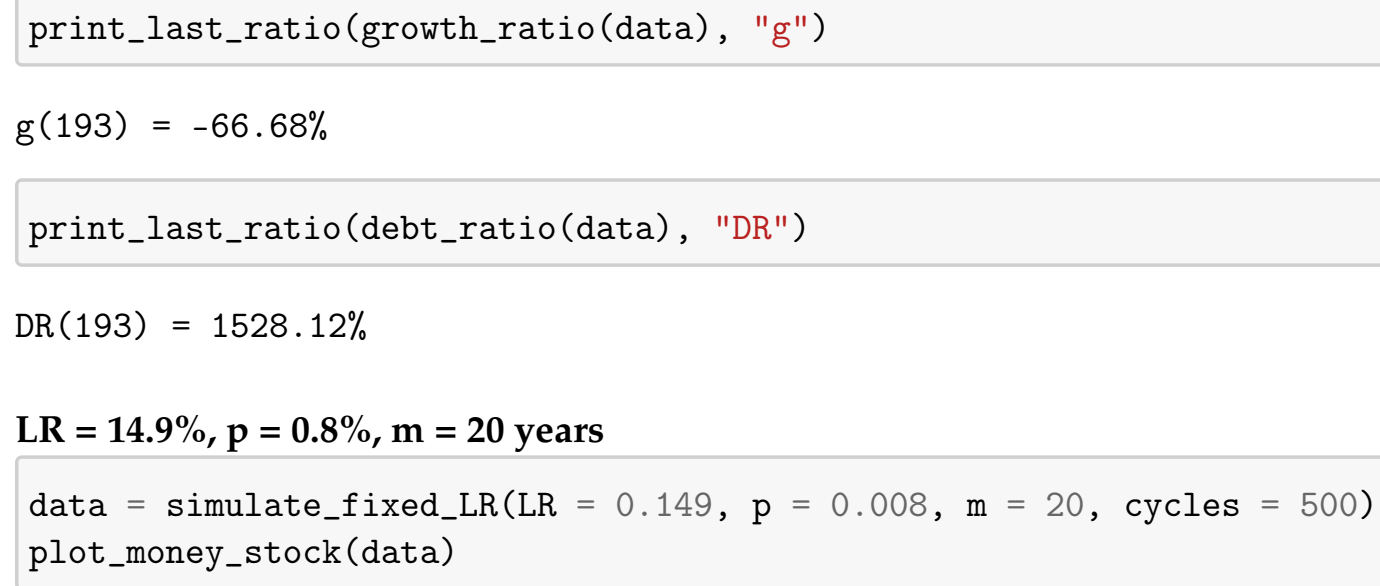

\section{Money stock (476 years)}

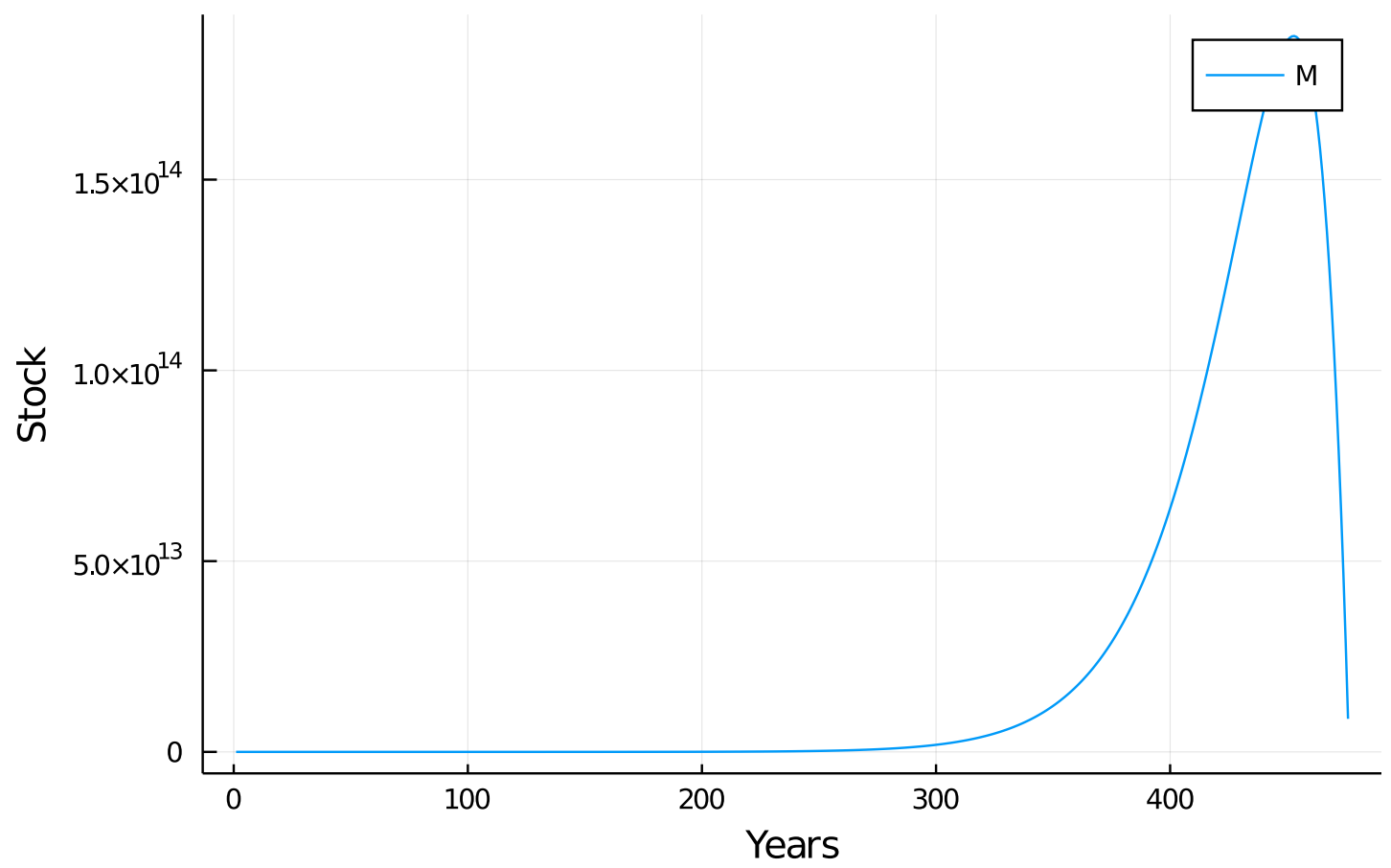

plot_growth_ratio(data) 


\section{Growth ratio (476 years)}



plot_debt_ratio(data)

Debt ratio (476 years)

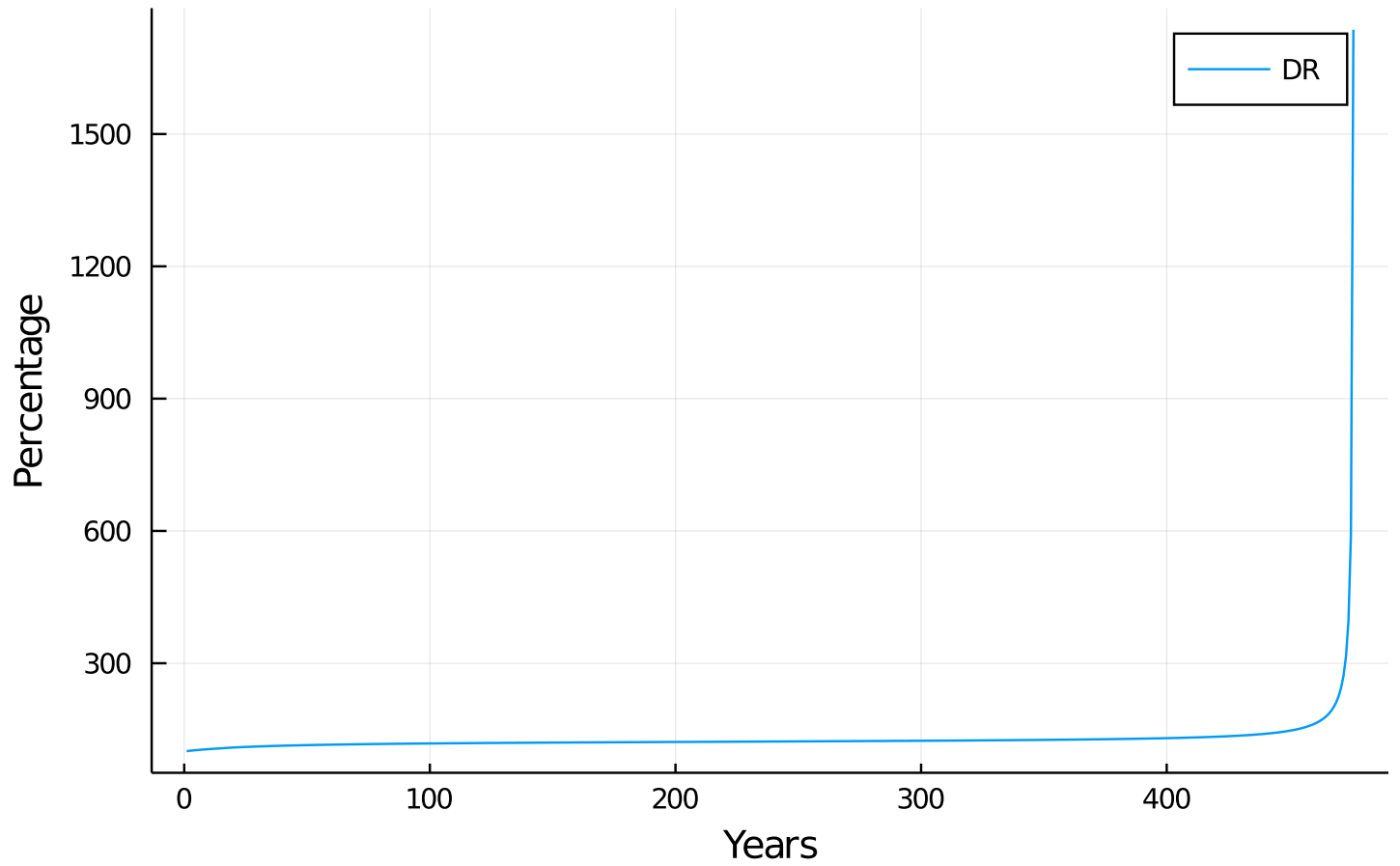




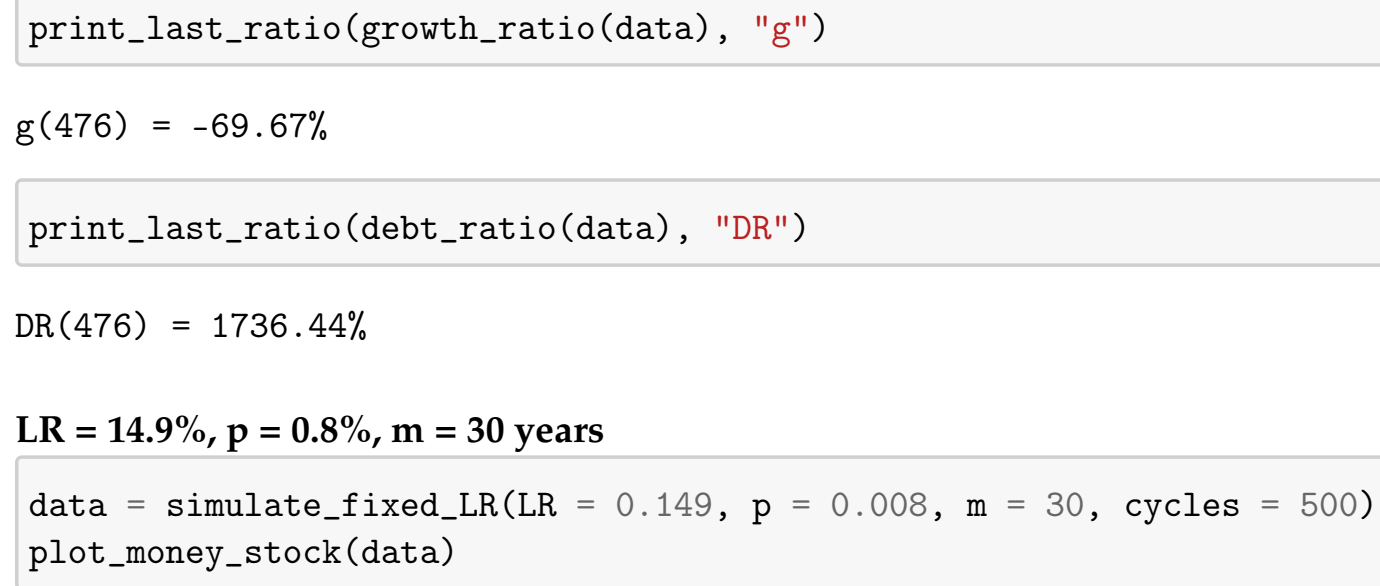

Money stock (500 years)

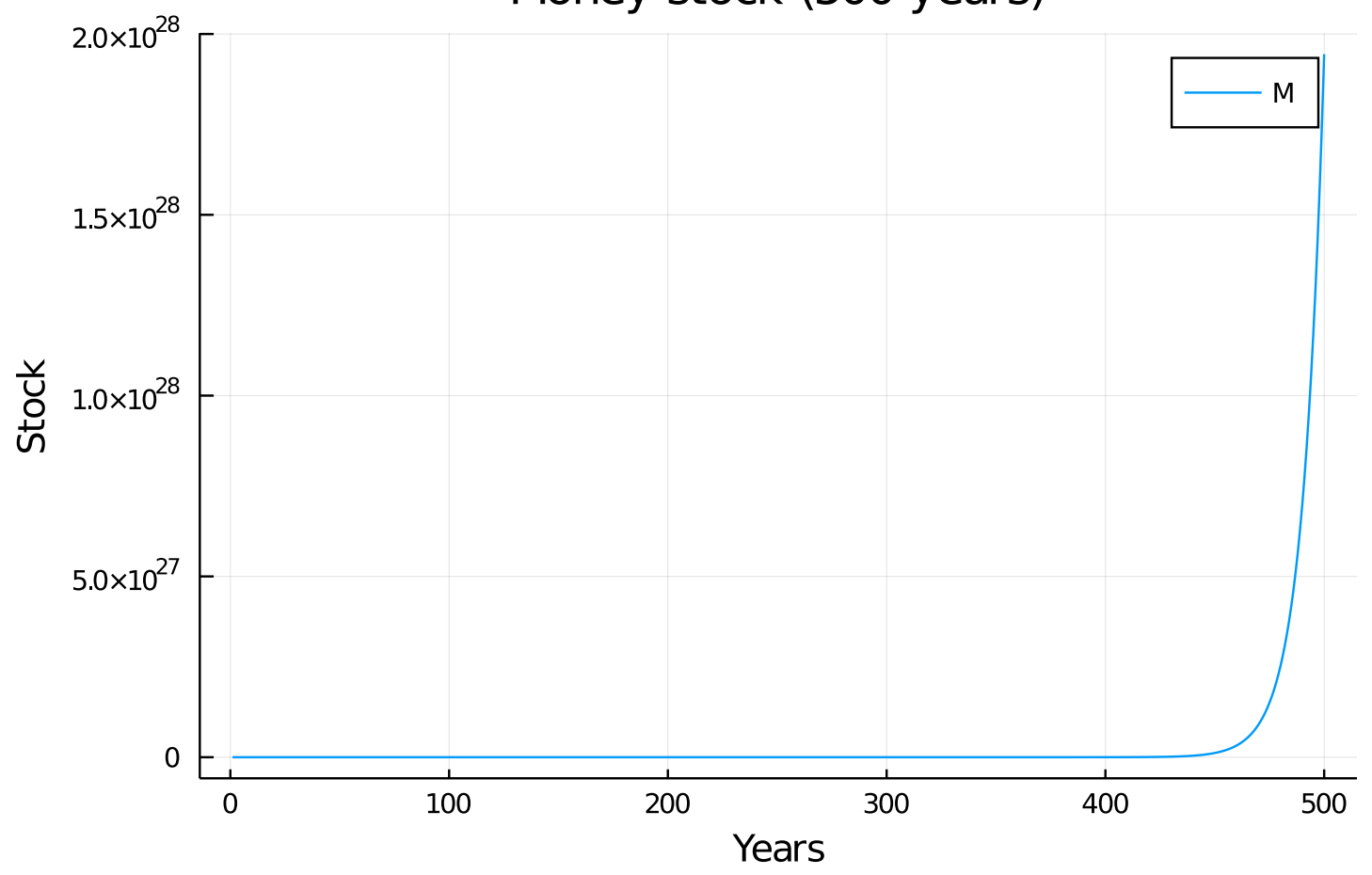

plot_growth_ratio(data) 


\section{Growth ratio (500 years)}

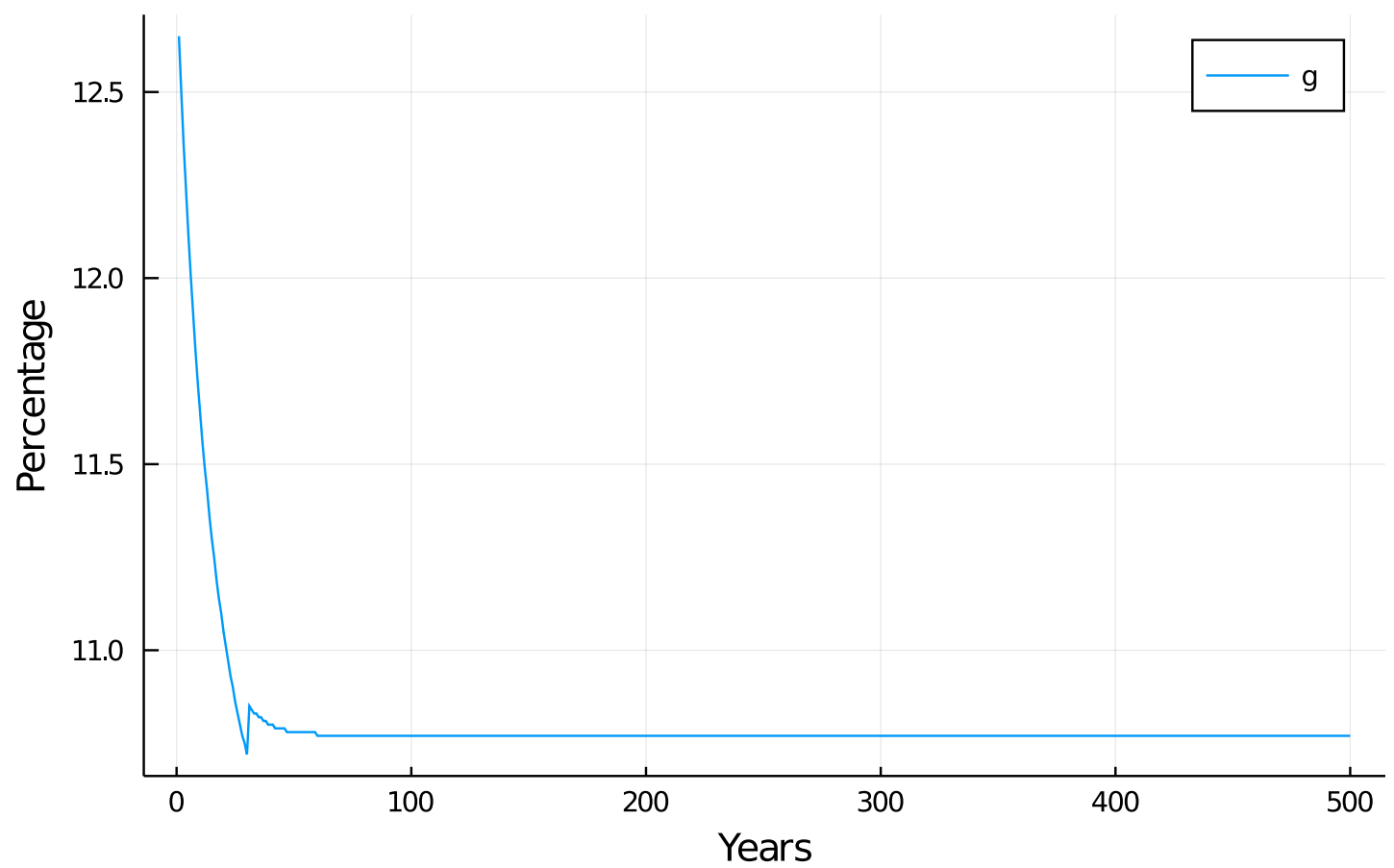

plot_debt_ratio(data)

Debt ratio (500 years)

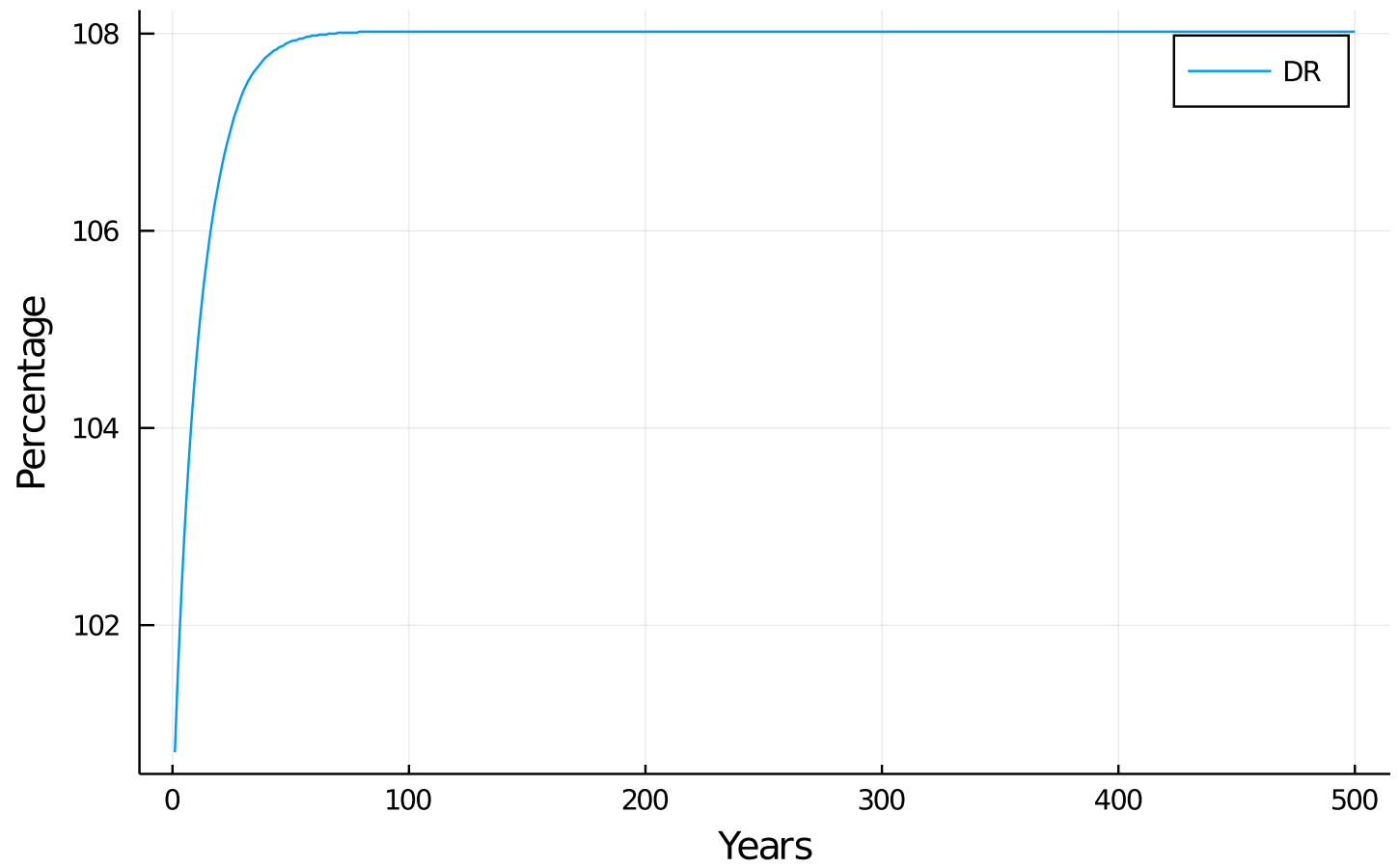


print_last_ratio(growth_ratio(data), "g")

$g(500)=10 \cdot 77 \%$

print_last_ratio(debt_ratio(data), "DR")

$\operatorname{DR}(500)=108.02 \%$

\section{Discussion}

\subsection{Observations}

\subsubsection{Fixed growth rate}

In the mathematical analysis $L$ has been factored out. Therefore loan maturity should have no no effect on $D R$. Indeed, when simulations are executed with different maturities, $D R$ is unaffected.

data $=$ simulate_fixed_g $(\mathrm{g}=0.05, \mathrm{p}=0.01, \mathrm{~m}=20$, cycles $=100)$

plot_debt_ratio(data, func_plot $=$ true)

Debt ratio (100 years)

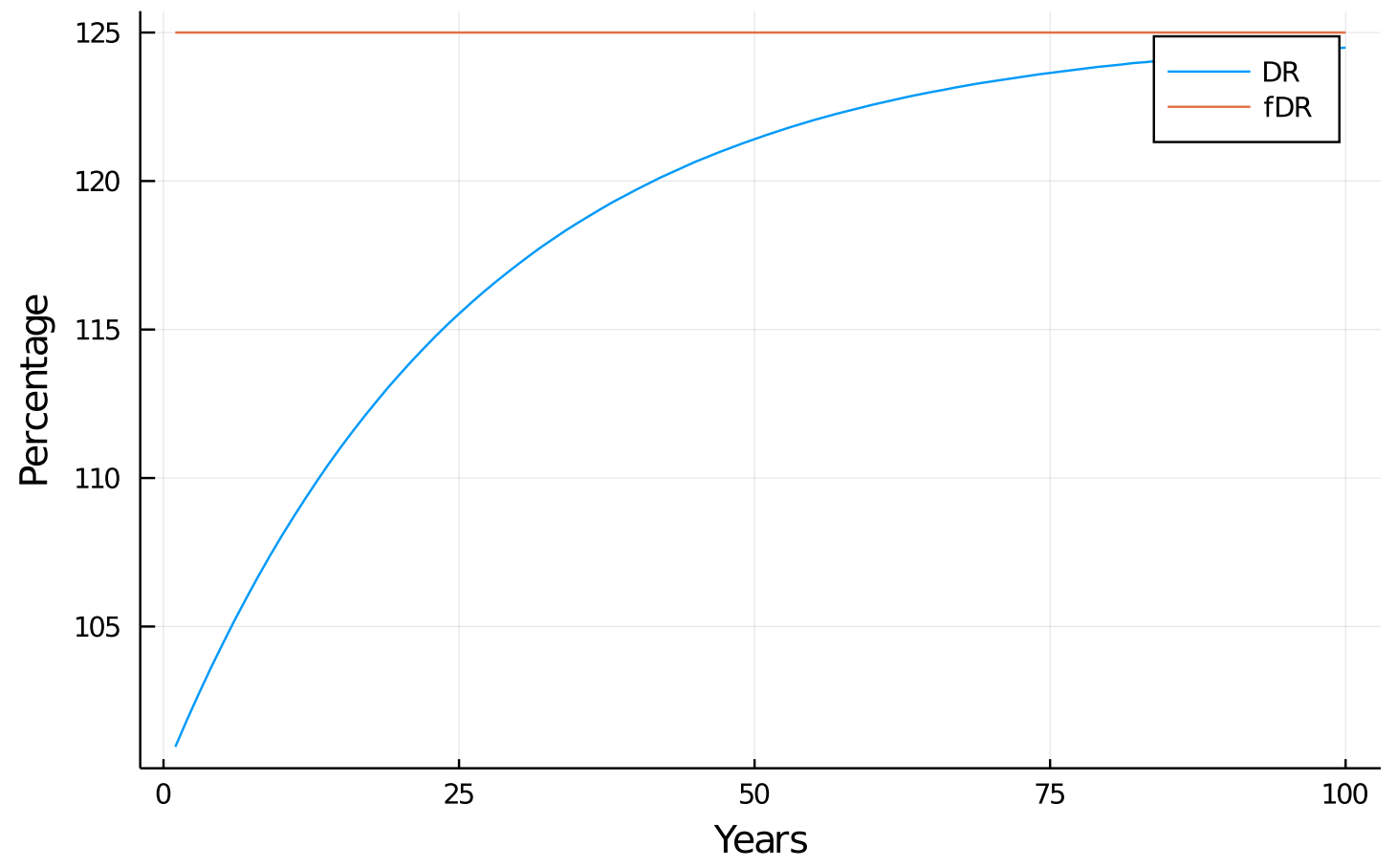




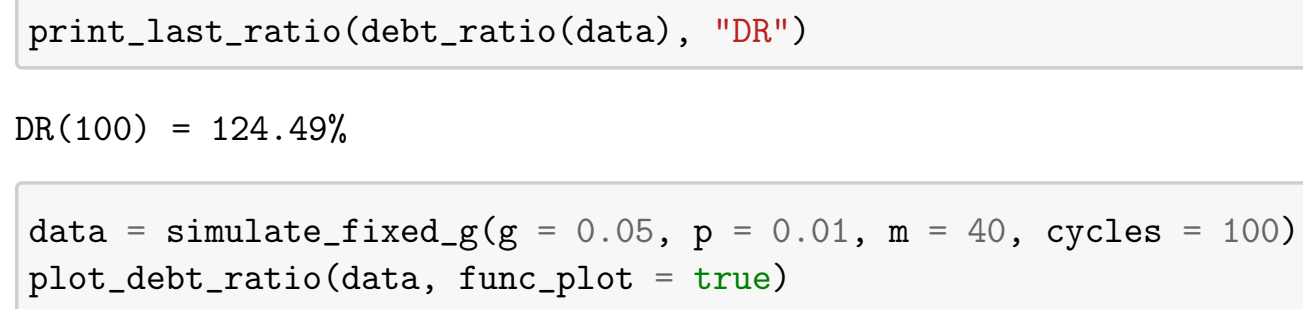

\section{Debt ratio (100 years)}

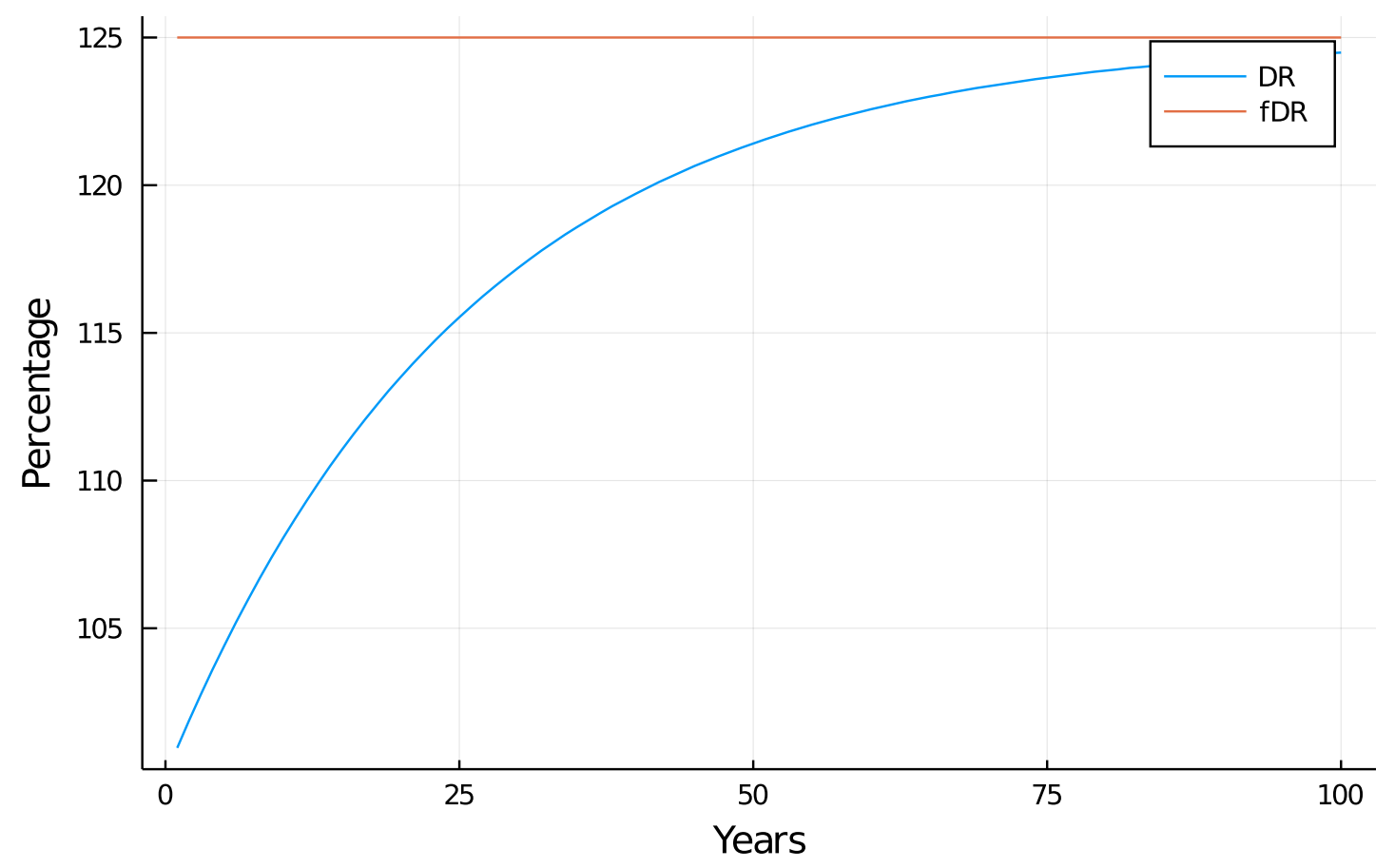

print_last_ratio(debt_ratio(data), "DR")

$\operatorname{DR}(100)=124.49 \%$

When $g$ is fixed and as long as $p<g$, the model remains stable and $D R$ converges to $\frac{g}{g-p}$. As soon as $p \geq g, D R$ no longer has an upper bound, thereby breaking the requirement for stability. This holds true even when $g$ is determined randomly each cycle, within limited bounds, and $p$ is set relative to this random $g$. When the model is run with $2 \% \leq g \leq 12 \%$, which are approximately the boundaries observed in fig. 2, variations in $p$, where $p$ is either smaller, equal or greater than $g$, result in trends similar to the simulations with a fixed $g$.

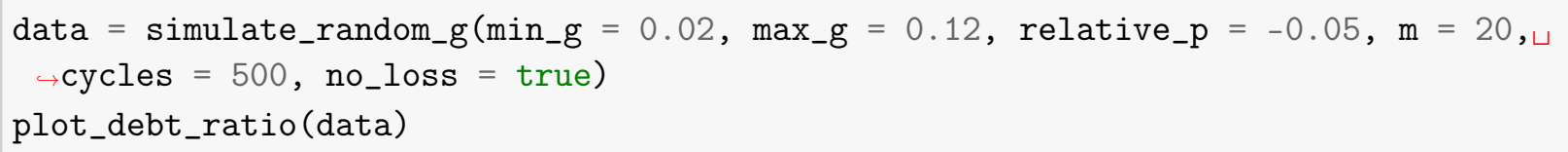


Debt ratio (500 years)

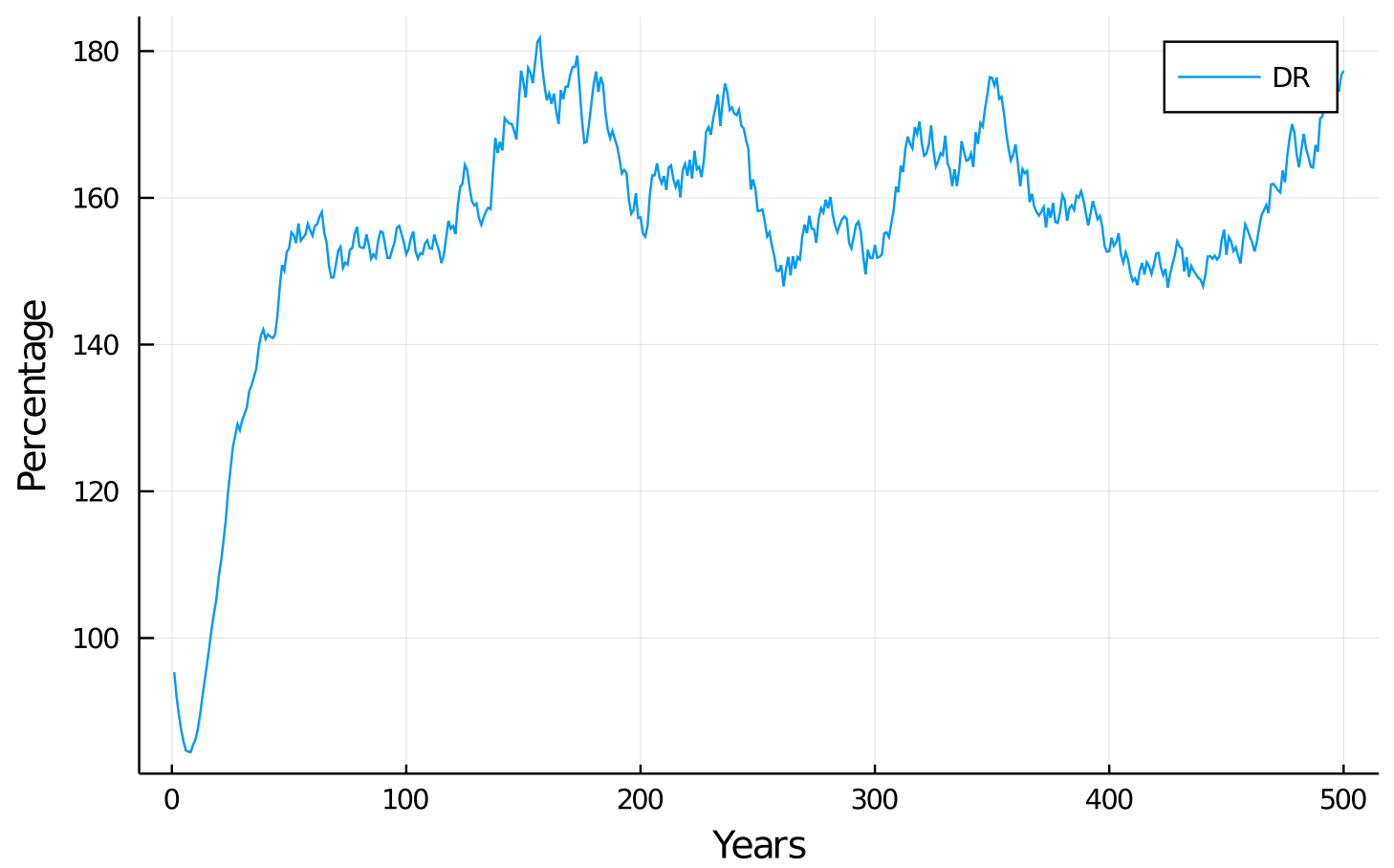

data $=$ simulate_random_g $\left(\min \_g=0.02, \max _{-} g=0.12\right.$, relative $\_p=0, m=20$, $\rightarrow$ cycles $=500$, no_loss $=$ true $)$

plot_debt_ratio(data) 


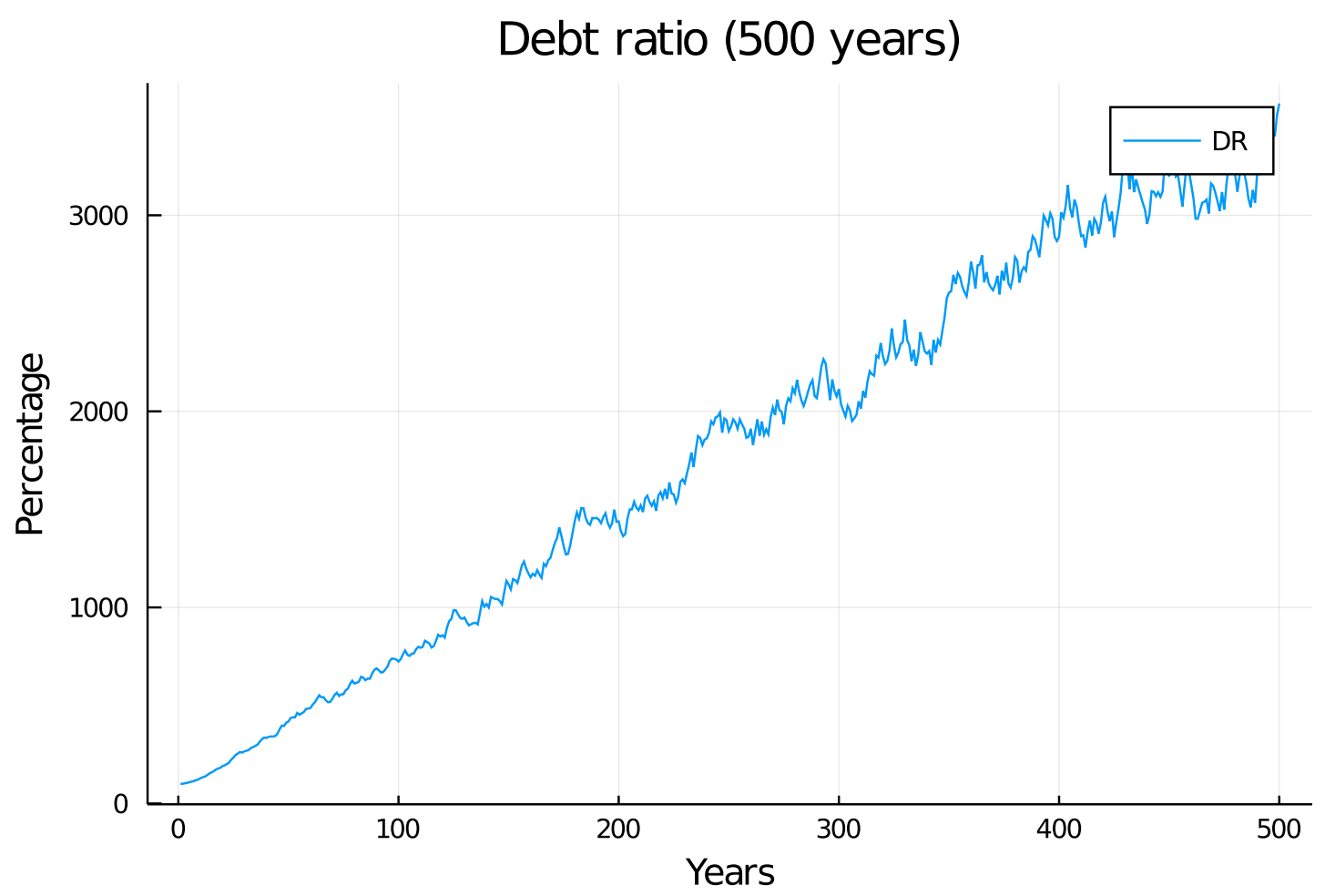

data $=$ simulate_random_g $\left(\min _{-} g=0.02, \max _{-} g=0.12\right.$, relative_p $=0.05, \mathrm{~m}=20$, $\rightarrow$ cycles $=500$, no_loss $=$ true)

plot_debt_ratio(data) 


\section{Debt ratio (500 years)}

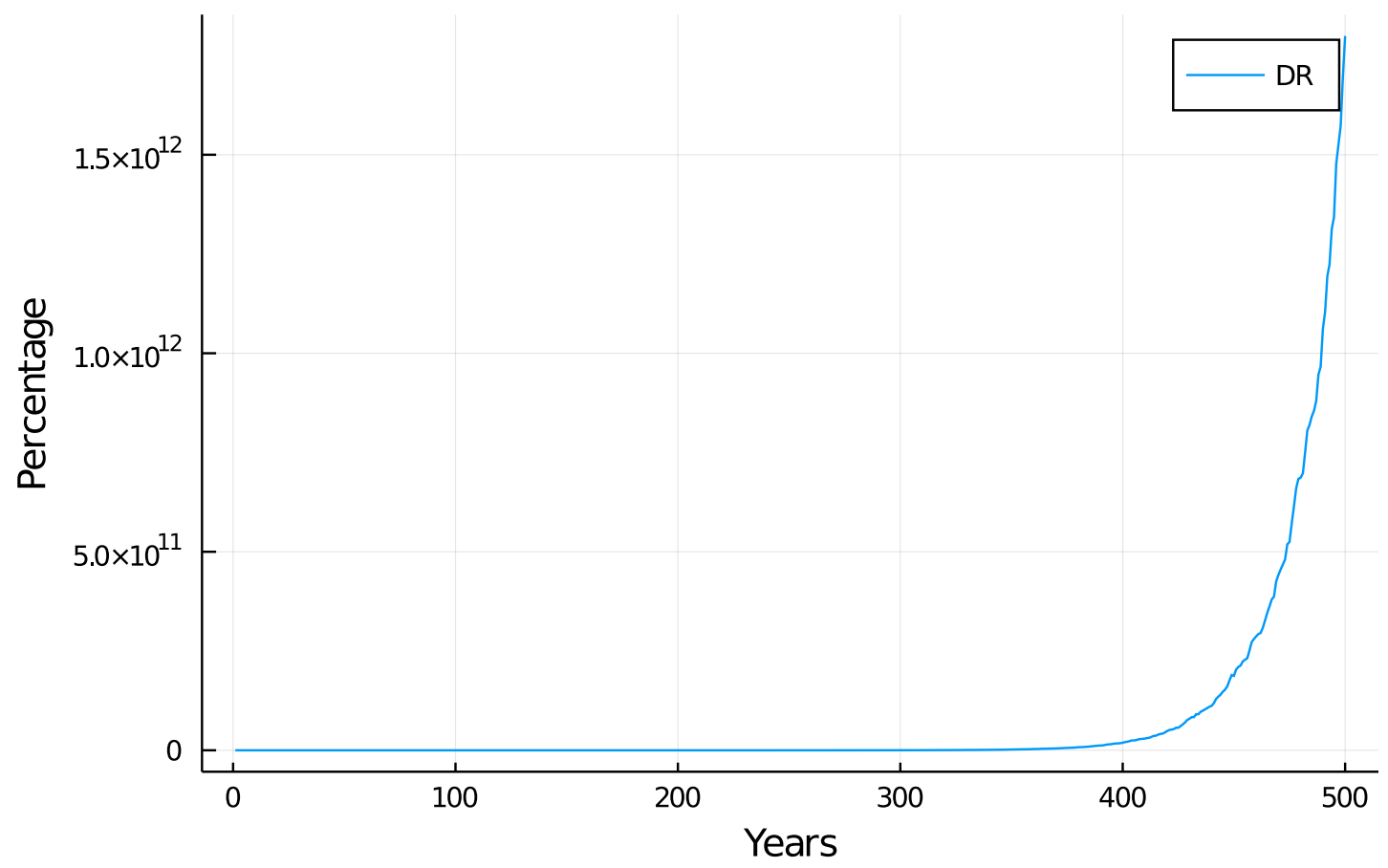

Very small differences between $p$ and $g$ lead to results which seem to deviate from the expectations but that stems from $D R$ being significantly higher and therefore, in the simulations, it takes longer before convergence occurs. This shows in the mathematical analyses.

Since loans are the driving force in the simulations they can also be used to calculate the resulting $L R$, which is the required $L R$ for a given combination of $p, g$ and $m$. LR follows the same pattern as $D R$ and becomes unbounded when $p \geq g$.

\subsubsection{Fixed loan ratio}

For parameters leading to a stable model, the results of fixed $L R$ simulations can be fed into fixed growth simulations to produce the same results.

For example, feeding the result, $g=4.75 \%$ from the $L R=15 \%, p=0.8 \%$ into a fixed $g$ simulation results in the same result for $D R$, namely $=120.25 \%$.

data $=$ simulate_fixed_g $(g=0.0475, p=0.008, m=20$, cycles $=500)$

plot_debt_ratio(data) 


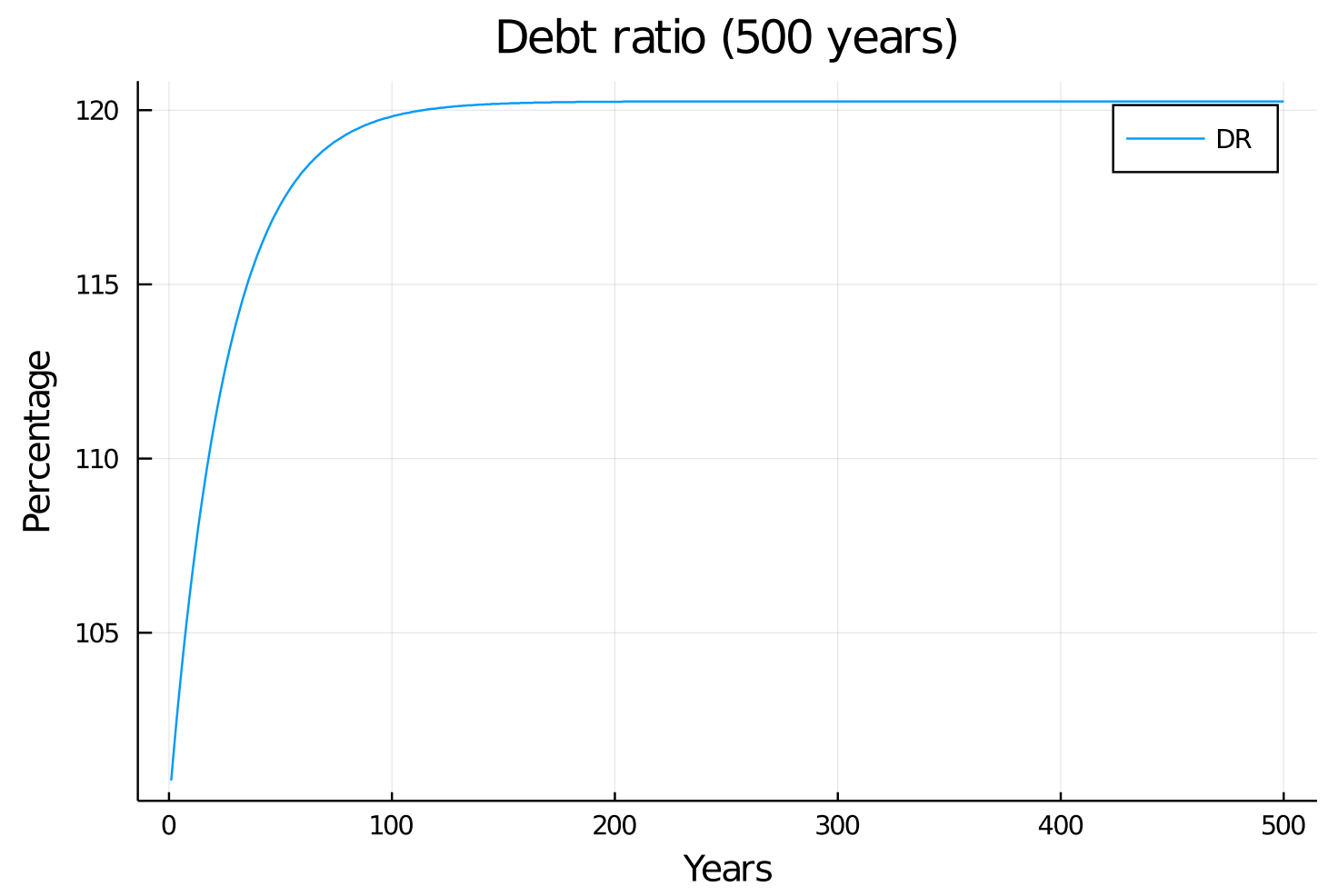

print_last_ratio(debt_ratio(data), "DR")

$\mathrm{DR}(500)=120 \cdot 25 \%$

\subsection{Steady state economy}

It can clearly be stated that discussion about the possibility of a steady state economy in conjunction with a debt based, interest bearing monetary system only makes sense if that monetary system is stable. The results from the simulations and the accompanying mathematical analyses therefore add a new perspective to the discussion.

Cahen-Fourot and Lavoie (Cahen-Fourot and Lavoie, 2016) state that, in order to have a steady state economy, banks and organisations must not accumulate wealth, i.e. a portion of accumulated wealth should be spent resulting in zero net wealth accumulation.

This is not contradicted by the simulations. Zero net wealth accumulation for banks would result in $p=0$, leading to a stable system $\forall g \geq 0$. However, no definite conclusions can be reached about whether a steady state economy can be reached since it is clear that the monetary system itself can be examined without taking economic parameters such as wages, production, consumption and private savings into account.

It is therefore suggested that the question about whether or not a post Keynesian money supply model is inherently incompatible with a steady state economy is restated as follows: Can a steady state economy realistically support a stable post Keynesian money supply model? 
It is observed that the stability of the model is dependent on $p<g$. For this to happen, a minimal $L R$ needs to exist. This minimal $L R$ is dependent on the behavior of the economic actors in the private sector. While theoretically $p$ and $m$ could be part of monetary policy, $L R$ can not.

If the position is taken that in a steady state economy businesses should be able to cover operating and depreciation costs with their revenues then there is a high likelihood that sufficient $L R$ would be lacking, leading to a negative $g$. This in turn would require the banking sector to operate at a loss in order to maintain stability, an event which is unlikely to occur.

The fact that the banking sector does not always answer positively to a loan demand puts additional strain on achieving the necessary $L R$.

Furthermore, if the balance sheet recession of Japan (Koo, 2013) is any indication, things look bleak. However, a declining $M$ could be the incentive needed to raise $L R$ but more research would be required before stating definitive conclusions.

Behavior of the economic actors - the private sector demanding loans and the banking sector approving loans and determining $p$ - should be included in the model. Is the banking sector willing to subject $p$ to $g$ ? Is the private sector willing to borrow sufficient amounts in order to satisfy the necessary LR? Which are the underlying incentives that drive borrowing and how strong are they in a steady state economy?

The most heated discussions in the debate about whether or not an inherent growth imperative exist in debt based, interest bearing monetary systems seems to be rooted in the definition of 'inherent growth imperative'. This definition is not the same for opposing sides of the argument. For those who claim there is no growth imperative, the real world behavior of the economic actors interacting with the monetary system is not taken into consideration when determining the existence of the growth imperative.

On the opposite side of the discussion, the necessary conditions for a steady state economy - banks and organisations freely distributing their profits - are claimed to be unrealistic and therefore a steady state can not be reached when using a debt based, interest bearing monetary system.

Realistically, behavior can not merely be assumed to match the requirements of a mathematical model. Excluding real world behavior and the underlying incentives of the economic actors would make this behavior external to the model and thereby result in money creation, driven by externalised behavior, to lean towards exogenity rather than endogenity, thereby undermining the endogenous character of post Keynesian money supply models. The articles from the literature study stating the absence of a growth imperative in a post Keynesian money supply model all assume that the behaviour of the economic actors falls in line with the needs of the model but no supportive arguments for the validity of these assumptions is made.

\subsection{Green economy}

The debate about whether or not debt based, interest bearing monetary systems demand a growing economy needs to be interpreted as part of a broader discussion about the sustainability of our current economic growth model. The de-growth movement ${ }^{3}$ argues that the growth model must be abandoned while growth proponents propose a green growth model which allows economic growth while at the same time reducing resource usage and abating negative impacts on climate and biodiversity. 
While most economists from both sides agree that action needs to be undertaken in order to mitigate the effects of resource extraction and waste disposal on our living environment, there is disagreement on the severity of the measurements which are necessary. Proponents of green growth (OECD, 2011, OECD, 2012, Bowen and Hepburn, 2014) advocate economic growth is needed in order to maintain prosperity and to lift people in developing countries out of poverty. Opponents state that sustained economic growth can not go hand in hand with a reduced impact on our environment and new models for well being and prosperity need to be developed (Parrique et al., 2019, Hickel, 2019).

Even though the debate is still ongoing, it seems that openness for a reconsideration of our economic growth model is on the rise (OECD, 2020, D'Alessandro et al., 2020). This might in part have to do with the complexity of achieving a green growth model. Implementing green growth is not a straightforward endeavour. A combination of adequate accounting methods, political will to implement green policies, which often come with a cost over the short term, and economic incentives for green investments is needed (Hallegatte et al., 2012, Nordhaus, 2015, Hepburn et al., 2018, Larissa et al., 2020, Dogaru, 2021, Kinsley Mua, 2017, Batrancea et al., 2020, Peterson K., 2021).

\subsection{Inflation/deflation}

Although inflation and deflation have no direct effect on the model, it influences $L R$. A continuous inflation makes sure the nominal size of loans - for the same purchases - rises with time, thereby helping to prop up $g$. Should deflation occur, nominal loan size would diminish, thereby putting a downward strain on $L R$ and as a consequence also on $g$. Therefore deflation would put the stability of the model at risk. This might be a reason why central banks vie to maintain positive inflation ratios.

\subsection{Model limitations}

The destabilised outcomes of the presented simulations do not unfold themselves in the real economy today.

This indicates that either $p<g$ or that other elements, missing from the model, are responsible for avoiding a collapse. What follows is a brief overview of those elements that could restore balance to the model.

\subsubsection{Quantitative easing}

Quantitative easing (QE), which has been applied extensively by central banks during the COVID19 pandemic, increases $M$ without resulting in increased debt. This reduces the $\frac{D}{M}$ ratio and also lowers the required $L R$, thereby reducing stress on the model. However, when the debt is settled or it is cleared from the balance sheets of central banks by reselling it to the financial markets, the reverse would happen. $M$ would decrease and increase stress on the model.

\subsubsection{Government spending}

Government spending can, under certain conditions, alleviate stress from the model.

When the government can spend money into existence, as claimed by MMT advocates (Kelton, 2020), $M$ can be increased in order to alleviate stress from the model. Decreasing $M$ through 
taxation holds the same risks as reselling debt bought up through QE would do, namely to increase stress on the model. $M$ decreases while $D$ remains the same, thereby raising $D R$.

In case the government can not spend money into existence they either have to borrow it from the private sector by issuing bonds or borrow it from banks.

When money is borrowed by issuing bonds and that money is then spent, no effects on the model occur. Money has moved from private investors to the government and back to private actors who are paid by the government. Both private investors and actors paid by the government are part of the private sector and $M$ does not change.

When the government borrows from a bank and then spends that money it has the same effect as a private actor making a bank loan.

Should governments hold on to money they borrowed it can be considered to be the same as accumulated wealth, i.e. 'dead' money.

\subsubsection{Banks selling debt at a loss}

If banks were to sell their debt to the financial market at a loss, this would effectively create 'debtless money' from credit money. Consider the following balance sheets to be the initial state:

\section{Bank balance sheet}

\begin{tabular}{ll}
\hline Assets & Liabilities \\
\hline Private debt $=100,000$ & Deposits $=80,000$ \\
& Equity $=20,000$ \\
\hline
\end{tabular}

Private sector balance sheet

\begin{tabular}{ll}
\hline Assets & Liabilities \\
\hline Deposits $=80,000$ & Private debt to bank =100,000 \\
& Equity $=-20,000$ \\
\hline
\end{tabular}

If the bank were to sell 20,000 of their private debt for 15,000, renaming it to a security, the resulting balance sheets would look like this:

Bank balance sheet

\begin{tabular}{ll}
\hline Assets & Liabilities \\
\hline Private debt $=80,000$ & Deposits $=65,000$ \\
& Equity $=15,000$ \\
\hline
\end{tabular}

\section{Private sector balance sheet}

\begin{tabular}{ll}
\hline Assets & Liabilities \\
\hline Deposits $=65,000$ & Private debt to bank $=80,000$
\end{tabular}




\begin{tabular}{ll}
\hline Assets & Liabilities \\
\hline Security $=20,000$ & Private debt to investor $=20,000$ \\
& Equity $=-15,000$ \\
\hline
\end{tabular}

The equity of the bank has been lowered by 5,000 and private sector equity has risen with an equal amount. From the perspective of systemic stability it doesn't matter that the debt is ever settled. Settlement of a debt held by private actors merely moves money around instead of destroying it, which is the case when a bank debt is paid off.

This process lowers $\frac{D}{M}$ from $125 \%$ to $123.08 \%$, thereby alleviating stress from the model. Banks selling debt at a loss is beneficial for the stability of the model. It is even better for the long term stability of the model when compared to QE and government spending because it essentially lowers $p$ and no trivial reverse process exists.

Solvency of banks would however be jeopardised should they lose more than they hold in equity.

\subsubsection{Loan defaulting}

When private actors default on their loans, a process similar to selling debt as a loss occurs. In this case the loss incurred by the bank equals the value of the loan minus the price they can sell claimed assets for.

This is beneficial for the long term stability of the model.

\section{Conclusion}

A common definition of the systemic boundaries of post Keynesian money supply systems is needed in order to be able to settle the argument about the existence of an inherent growth imperative in those systems.

The economic actors and their real world behavior and underlying incentives should be considered as an integral part of the monetary system. An endogenous money supply can simply not exist without a loan demand coming from the economic actors. Even the model presented here would not generate a money supply without this demand. Therefore it can be stated that a debate about intrinsic growth imperatives without the inclusion of economic actors and their real world behavior makes little sense.

A restatement of the inherent growth imperative research question is suggested. Can a steady state economy realistically support a stable post Keynesian money supply model? Stability being defined as having a bounded debt ratio $(D R)$. This requires extensive behavioral research on simulated steady state economies.

The model observations make it clear that stability can only be achieved when the net profit ratio of the aggregate bank $(p)$, relative to their debt assets $(D)$, is less than the growth rate $(g)$ of the money supply $(M)$. The implication of this condition is that there must exist an adequate loan ratio $(L R)$ and thus an adequate loan demand from the private sector.

These observations can not be easily disregarded. Under the assumption that the post Keynesian money supply theory is correct, the dynamics presented here must be at play. They are inherent to 
any debt based monetary system where banks make a profit. Events like QE, loan defaulting and banks selling off loans at a loss counter destabilisation by artificially boosting $g$ and/or lowering $p$ but the frequency and circumstances which cause these should be investigated further. It would therefore be interesting to revisit the analysis on systemic banking crises, which was performed by the IMF (Laeven and Valencia, 2018), with this information in mind.

This can be seen as an opportunity to contemplate about pragmatic action towards a green economy. Although definite answers on a growth imperative remain illusive, there is a strong indication that a sufficient $L R$ might not be achievable in a steady state economy. Should the implementation of a green growth economy prove to be impossible or inadequate it would mean that either the current system must be permanently modified in order to ensure that $p<g$ or the transition to a new monetary system must be prepared. It might therefore be wise to spend more effort on alternatives for both the current economic growth model and debt based, interest bearing monetary systems.

From the perspective of scientific rigor and prudence towards changing large scale systems it is preferable to arrive at definite answers before taking action. Considering the complexity of the economic system as a whole, combined with the equally complex topic of incentive driven behaviour, this is a daunting task. Especially since time is an issue too. Climate reports become increasingly alarming (IPCC, 2018, 2019) and at the UN conference of $2019^{4}$ it was claimed there was only 11 years left to turn the tide on climate change. Pragmatic, innovative and experimental approaches like using large scale game simulations (Ramsey and Renault, 2020, Li et al., 2021) could provide a solution.

\section{References}

Arnsperger, C., Bendell, J., Slater, M., 2021. Monetary Adaptation to Planetary Emergency: Addressing the Monetary Growth Imperative.

Batrancea, I., Batrancea, L., Maran Rathnaswamy, M., Tulai, H., Fatacean, G., Rus, M.-I., 2020. Greening the Financial System in USA, Canada and Brazil: A Panel Data Analysis. Mathematics 8, 2217. https://doi.org/10.3390/math8122217

Bowen, A., Hepburn, C., 2014. Green growth: an assessment. Oxford Review of Economic Policy 30, 407-422. https://doi.org/10.1093/oxrep/gru029

Cahen-Fourot, L., Lavoie, M., 2016. Ecological monetary economics: A post-Keynesian critique. Ecological Economics 126, 163-168. https://doi.org/10.1016/j.ecolecon.2016.03.007

Caiani, A., Godin, A., Caverzasi, E., Gallegati, M., Kinsella, S., Stiglitz, J.E., 2016. Agent basedstock flow consistent macroeconomics: Towards a benchmark model. Journal of Economic Dynamics and Control 69, 375-408. https://doi.org/10.1016/j.jedc.2016.06.001

D’Alessandro, S., Cieplinski, A., Distefano, T., Dittmer, K., 2020. Feasible alternatives to green growth. Nat Sustain 3, 329-335. https:/ /doi.org/10.1038/s41893-020-0484-y

Deutsche Bundesbank, 2017. "The role of banks, nonbanks and the central bank in the money creation process." Monthly Report, Deutsche Bundesbank.

Dogaru, L., 2021. Green Economy and Green Growth-Opportunities for Sustainable Development, in: The 14th International Conference on Interdisciplinarity in Engineering-INTER-ENG 2020. MDPI, Mures, Romania. https:/ / doi.org/10.3390/proceedings2020063070 
Farley, J., Burke, M., Flomenhoft, G., Kelly, B., Murray, D.F., Posner, S., Putnam, M., Scanlan, A., Witham, A., 2013. Monetary and Fiscal Policies for a Finite Planet. Sustainability 5, 2802-2826. https://doi.org/10.3390/su5062802

Godley, W., Lavoie, M., 2012. Monetary Economics. Palgrave Macmillan UK, London. https://doi.org/10.1007/978-1-137-08599-3

Godley, W., 2014 Towards a Reconstruction of Macroeconomics Using a Stock Flow Consistent (SFC) Model 24.

Gross, M., Siebenbrunner, C., 2019. Money Creation in Fiat and Digital Currency Systems. IMF Working Papers 19 [Online]. Available at: https://doi.org/10.5089/9781513521565.001

Hallegatte, S., Heal, G., Fay, M., Treguer, D., 2012. From Growth to Green Growth - a Framework (No. w17841). National Bureau of Economic Research, Cambridge, MA. https://doi.org/10.3386/w17841

Hepburn, C., Pfeiffer, A., Teytelboym, A., 2018. Green Growth - Oxford Handbooks, in: The New Oxford Handbook of Economic Geography. Oxford University Press, p. 27. https://www.doi.org/10.1093/oxfordhb/9780198755609.013.44

IPCC, 2018. Special report - Global warming of $1.5^{\circ} \mathrm{C}$. https://www.ipcc.ch/sr15/

IPCC, 2019. Special report - Climate Change and Land. https://www.ipcc.ch/srccl/ IPCC, 2019. Special report - The Ocean and Cryosphere in a Changing Climate. https:/ /www.ipcc.ch/srocc/

Jackson, T., Victor, P.A., 2015. Does credit create a 'growth imperative'? A quasistationary economy with interest-bearing debt. Ecological Economics 120, 32-48. https://doi.org/10.1016/j.ecolecon.2015.09.009

Jason Hickel \& Giorgos Kallis (2019): Is Green Growth Possible?, New Political Economy, https:/ / doi.org/10.1080/13563467.2019.1598964

Kelton, S., 2020. The deficit myth: modern monetary theory and how to build a better economy. John Murray.

Kinsella, S., O'Shea, T., 2011. Solution and Simulation of Large Stock Flow Consistent Monetary Production Models Via the Gauss Seidel Algorithm. SSRN Journal. https://doi.org/10.2139/ssrn.1729205

Kinsley Mua, K., 2017. Green Financing. SSRN Electronic Journal. https://doi.org/10.2139/ssrn.2940765

Koo, R.C., 2013. Balance sheet recession as the 'other half' of macroeconomics. EJEEP 10, 136-157. https://doi.org/10.4337/ ejeep.2013.02.01

Laeven, L., Valencia, F., 2018. Systemic Banking Crises Revisited. IMF Working Papers 18, 1. https://doi.org/10.5089/9781484376379.001

Larissa, B., Maran, R.M., Ioan, B., Anca, N., Mircea-Iosif, R., Horia, T., Gheorghe, F., Ema Speranta, M., Dan, M.I., 2020. Adjusted Net Savings of CEE and Baltic Nations in the Context of Sustainable Economic Growth: A Panel Data Analysis. JRFM 13, 234. https://doi.org/10.3390/jrfm13100234

Lavoie, M., Godley, W., 2002 Kaleckian models of growth in a coherent stock-flow monetary framework: a Kaldorian view 36. 
Li, Z., Lin, P.-H., Kong, S.-Y., Wang, D., Duffy, J., 2021. Conducting large, repeated, multi-game economic experiments using mobile platforms. PLoS ONE 16. https://doi.org/10.1371/journal.pone.0250668

Lietaer, B., Arnsperger, C., Goerner, S., Brunnhuber, S., 2012. Money - Sustainability: The Missing Link.

McLeay, M., Radia, A., 2014. Money creation in the modern economy.

Nikiforos, M., Zezza, G., 2017. Stock-flow Consistent Macroeconomic Models: a Survey. Levy Economics Institute. https://www.levyinstitute.org/pubs/wp_891.pdf

Nordhaus, W., 2015. Climate Clubs: Overcoming Free-riding in International Climate Policy. American Economic Review 105, 1339-1370. https:/ / doi.org/10.1257/aer.15000001

OECD, 2011. 'Towards green growth' https://www.oecd.org/greengrowth/ 48012345.pdf

OECD, 2012. OECD Environmental Outlook to 2050: The Consequences of Inaction, Paris, Organization for Economic Cooperation and Development. https://www.oecd.org/g20/topics/energyenvironment-green-growth/oecdenvironmentaloutlookto2050theconsequencesofinaction.htm

OECD, 2020. Beyond Growth: Towards a New Economic Approach, New Approaches to Economic Challenges. OECD. https://doi.org/10.1787/33a25ba3-en

Parrique T., Barth J., Briens F., C. Kerschner, Kraus-Polk A., Kuokkanen A., Spangenberg J.H., 2019. Decoupling debunked: Evidence and arguments against green growth as a sole strategy for sustainability. European Environmental Bureau.

Peterson K., O., 2021. Digital Finance, Green Finance and Social Finance: Is There a Link? SSRN. https://doi.org/10.2139/ssrn.3786881

Ramsey, D.M., Renault, J. (Eds.), 2020. Advances in Dynamic Games: Games of Conflict, Evolutionary Games, Economic Games, and Games Involving Common Interest, Annals of the International Society of Dynamic Games. Springer International Publishing, Cham. https://doi.org/10.1007/978-3-030-56534-3

Richters, O., Siemoneit, A., 2017. Consistency and stability analysis of models of a monetary growth imperative. Ecological Economics 136, 114-125.

Werner, R.A., 2016. A lost century in economics: Three theories of banking and the conclusive evidence. International Review of Financial Analysis 46, 361-379 https://doi.org/10.1016/j.irfa.2015.08.014

Werner, R.A., 2014. Can banks individually create money out of nothing? - The theories and the empirical evidence. International Review of Financial Analysis 36, 1-19 https:/ / doi.org/10.1016/j.irfa.2014.07.015

\section{Appendix A - Source code}

Source code for the model is implemented in Julia and is available at: https://github.com/HapponomyOrg/MoneySim.jl

The source code uses the EconoSim.jl v0.2.0 package which is available at: https://github.com/HapponomyOrg/EconoSim.jl 


\section{Footnotes}

1: Eurostat website: https://sdw.ecb.europa.eu/

2: Since cash is not used in the model, M2 is not exactly the same as $M$ but it is the closest real world measurement to it.

3: https://www.degrowth.info/en/ https://degrowth.org

4: UN Meeting Coverage. Only 11 Years Left to Prevent Irreversible Damage from Climate Change, Speakers Warn during General Assembly High-Level Meeting. https://www.un.org/press/en/2019/ga12131.doc.htm 